\title{
Organic Pollutants Treatment from Air Using Electron Beam Generated Nonthermal Plasma - Overview
}

\author{
Yongxia Sun ${ }^{1}$ and A. G. Chmielewski1,2 \\ IInstitute of Nuclear Chemistry and Technology, Warsaw, \\ 2 University of Technology, Warsaw, \\ Poland
}

\section{Introduction}

The municipal and industrial activities of man lead to environment degradation. The pollutants are emitted to the atmosphere with off-gases from industry, power stations, residential heating systems and vehicles. Organic pollutants, mainly volatile organic compounds (VOCs), which are emitted into atmosphere cause stratospheric ozone layer depletion, ground level photochemical ozone formation, and toxic or carcinogenic human health effects, contribute to the global greenhouse effect, accumulate and persist in environment. Regulation on organic pollutants emission into atmosphere has been enforced in many countries. Electron beam (EB) generated nonthermal plasma technology is one of the most promising technologies which has been successfully demonstrated on industrial scale coal fired power plants to remove $\mathrm{SO}_{2}$ and $\mathrm{NOx}$ from waste off-gases; Meanwhile EB technology has been tested in pilot scale to remove dioxins and Polycyclic aromatic hydrocarbons (PAHs) from off-gases generated from solid waste incinerators and coal fired power plants, good results were obtained. It is a very promising technology to treat multiple pollutants including $\mathrm{SO}_{2}$, NOx and organic pollutants simultaneously from industrial off-gases. The principle of EB process to decompose pollutants is following. When the energy of the fast electrons is absorbed in the carrier gas, it causes ionization and excitation processes of the nitrogen, oxygen or water molecules in the carrier gas. Primary species and secondary electrons are formed, and the latter are thermalized within $1 \mathrm{~ns}$ in air at 1 bar pressure. These primary species such as ions, radicals or other oxidizing species and the thermalized secondary electrons react with pollutants by a series of reactions to cause pollutants decomposition.

Organic pollutants treatment using EB technology has been studied intensively in recent 30 years mainly in laboratory scale. However less work has been done to review this technology development on organic pollutants treatment. This chapter aims a comprehensive description of organic pollutants treatment using EB generated nonthermal plasma technology. General description of EB generated nonthermal plasma technology will be given in section 2, organic pollutants treatment from air and its recent development will be overviewed in sections $3 \& 4$, and general mechanism of organic pollutants decomposition in air will be discussed in section 5 . 


\section{Electron beam (EB) generated nonthermal plasma technology}

\subsection{History}

Wet flue gas desulphurisation (FGD) and selective catalytic reduction (SCR) can be applied for flue gas treatment and $\mathrm{SO}_{2}$ and $\mathrm{NOx}$ emission control. VOCs are usually adsorbed on active carbon, but this process is rarely used for lean hydrocarbon concentrations up to now. All these technologies are complex chemcial processes and waste, like wastewater, gypsum and used catalyses, are generated(Srivastava et al., 2001).

EB technology is among the most promising advanced technologies of new generation. This is a dry-scrubbing process of simultaneous $\mathrm{SO}_{2}$ and $\mathrm{NOx}$ removal, where no waste except the by-product is generated. EB technology for air treatment was first used by Japanese scientists in 1970-1971 to study $\mathrm{SO}_{2}$ removal using an electron from linear accelerator (2-12 $\mathrm{MeV}, 1.2 \mathrm{~kW}$ ). A dose of $50 \mathrm{kGy}$ at $100^{\circ} \mathrm{C}$ led the conversion of $\mathrm{SO}_{2}$ to an aerosl of sulphuric acid droplets, which were easily removed (Machi, 1983). In 1981, Slater (1981) used EB technology to study the decomposition of low concentrations of vinyl chloride(VC) in different base gas (air, nitrogen, and argon).

\subsection{EB accelerator}

In physics and chemistry, plasma is a state of matter similar to gas in which a certain portion of particles are ionised. Nonthermal plasma means only a small fraction (for example 1\%) of the gas molecules are ionized. The most common method for plasma generation is by applying an electric field to a neutral gas. Electrons emitted from electron beam accelerators can ionize gas mixture and generate nonthermal plasma.

More than 1000 accelerators haven been used in the field of radiation chemistry and radiation processing (Zimek, 1995). The reduction of $\mathrm{SO}_{2}$ and $\mathrm{NOx}$ pollutants from flue gases, emitted during fuel combustion in electrical power and heat production, is one of the radiation process which were successfully demostrated in industrail scale in electric power station (EPS) Pomorzany, Szczecin, Poland (Chmielewski et al, 2004a) . A basic principle of an accelerator is that the electric field acts on electrons as charged particles and give them energy equal to the voltage difference accross the acceleration gap. The accelerator types are mainly determined by the method by which electron field is generated. There are three type accelerators used in air pollutants treatment: transformer accelerator, UHF accelerator and linear microwave accelerator (Zimek, 2005). High power accelerators have been developed to meet specific demands of environmental application and high throughput processes to increses the capacity and reduce unit cost of operation. Table 1 lists accelerators for radiation processing (Zimek, 2005).

\begin{tabular}{|l|l|l|l|}
\hline Accelerator type & Direct DC & $\begin{array}{l}\text { UHF } \\
100-200 \mathrm{MHz}\end{array}$ & $\begin{array}{l}\text { Linear } \\
1.3-5.8 \mathrm{GHz}\end{array}$ \\
\hline Beam current & $<1.5 \mathrm{~A}$ & $<100 \mathrm{~mA}$ & $<100 \mathrm{Ma}$ \\
\hline Energy range & $0.1-5 \mathrm{MeV}$ & $0.3-10 \mathrm{MeV}$ & $2-10 \mathrm{MeV}$ \\
\hline Beam power & $400 \mathrm{~kW}$ & $700 \mathrm{~kW}$ & $150 \mathrm{~kW}$ \\
\hline Efficiency & $60-80 \%$ & $25-50 \%$ & $10-20 \%$ \\
\hline
\end{tabular}

Table 1. Accelerator for radiation processing (recent development) 


\subsection{Terminology}

In radiation application in environmental protection, there are three terms to be mentioned, dose, G-value and removal efficiency (Re) or decomposition efficiency(De).

In radiation process, it is very important to consider energy consumption for decomposition of pollutants, how much energy (unit: $\mathrm{kJ}$ ) is consumed/absorbed to decompose amount of pollutants in the base gas (unit: kg). Energy absorbed by per amount of gas is defined as a term of dose, unit is $\mathbf{k G y} .1 \mathrm{kGy}=1 \mathrm{~kJ} / \mathrm{kg}$

G-value is defined as the number of molecules of product formed, or of starting material changed, for every $100 \mathrm{eV}$ of energy absorbed. The $\mathrm{G}$ value is related to the ionic yield (M / N) by the expression (Willis and Boyd, 1976):

$$
\mathrm{G}(\text { molecules / } 100 \mathrm{eV})=(\mathrm{M} / \mathrm{N}) \times(100 / \mathrm{W})
$$

Where $W$ ( measured in electronvolts) is the mean energy required to from an ion pair in the material being irradiated. $G$ value of 1 molecule $/ \mathbf{1 0 0} \mathrm{eV}$ is equal to a radiation chemical yield of 0.1036 pmol. J-1.

Removal efficiency (Re) or decomposition efficiency (De) of organic pollutants is defined as below:

$$
\operatorname{Re}=\left(\mathrm{C}_{0}-\mathrm{C}_{\mathrm{i}}\right) / \mathrm{C}_{0}
$$

where $\mathrm{C}_{0}$ is initial concentration of organic pollutants, unit: $\mathrm{ppm}(\mathrm{v} / \mathrm{v})$;

$\mathrm{C}_{\mathrm{i}}$ is concentration of organic pollutants at $\mathrm{i}$ kGy absorbed dose, unit: ppm (v/v).

\section{EB treatment organic pollutants}

There are two systems applied to study organic pollutants in laboratory scale by using EB generated nonthermal plasma - flow system and batch system. Flow system contains one step: preparation and irradiation of the gas mixture which contains organic pollutants are carried out in on-line system. Batch system contains two steps: first step is to prepare gas mixture which contains organic pollutants into a sealed container, the second step is to put this sealed container under electron beam accelerator for irradiation.

\subsection{Aliphatic organic pollutants degradation in flow system under EB-irradiation 3.1.1 Concentration of aliphatic organic pollutants vs. dose}

There have been some previous studies of chlorinate hydrocarbons' decomposition in plasma reactors. Slater(1981) studied the decomposition of low concentrations of vinyl chloride $(\mathrm{VC})$ in air, nitrogen, and argon in an electron beam generated plasma reactor. It was found that VC can be effectively removed by electron-beam irradiation at concentrations 3-500 ppm from room-temperature host-gas streams of argon, nitrogen and air. And at low dose the specific energy required falled in the range $2.5<\mathrm{G}<10$ molecules removed per $100 \mathrm{eV}$. $\mathrm{HCl}$ was one of main products.

Vitale et al.(1997a) studied decomposition low concentration of ethyl chloride (EC) and vinyl chloride $(\mathrm{VC})$ in atmospheric air streams by an electron beam generated plasma reactor. The gas was prepared by mixing dry air with standard VC (3925ppm VC in air) or EC (3717ppm EC in air). The gas entered the reactor at atmospheric pressure and ambient temperature. The electrons entered the front of the reactor, and VOC contaminated gas entered the rear of the reactor. The VOC contaminated gas thus flowed counter-current to 
the electron beam. A Hewlett-Packard 5890 gas chromatograph and a HP-5971-A mass spectrometer were used to analyze VOCs concentration. The energy requirements for $90 \%$ decomposition of VC and EC were reported as a function of inlet concentration. VC requires less energy for decomposition than EC.

Similar experiments were carried out to decompose 1,1-dichloroethane (1,1-DCA), 1,1dichloroethylene (1,1-DCE),1,1,1-trichloroethane (1,1,1-TCA), trichloroethylene (TCE) using EB by the same research group (Vitale et al., 1996, 1997b-d). It was found that decomposition efficiency of chlorinated compounds was : TCE > 1,1-DCE > 1,1-DCA, 1,1,1-TCA.

Won et al. (2002) studied the decomposition of perchloroethylene (PCE), trichloroethylene (TCE), dichloroethylene (DCE) in dry air. An electron accelerator of ELV type, with electron energy $0.7 \mathrm{MeV}$, maximum beam current $35 \mathrm{~mA}$, maximum power $25 \mathrm{~kW}$ was used for irradiation. Over $80 \%$ TCE was decomposed at $20 \mathrm{kGy}$ dose at initial concentration below $2000 \mathrm{ppm}$. The order of decomposition efficiency of these compounds was: TCE > PCE > DCE. Hirota et al. (2004) studied dichloromethane decomposition under EB irradiation and found that it was very difficult to treat dichloromethane.

For non-chlorinated organic compounds, 20 VOCs divided into five groups were investigated by Hirota et al.(2004), among them, 13 VOCs were alipahtic organic compounds. The order of decomposition VOCs in air was: cyclohexadiene $>$ cyclohexane $>$ benzene (group I); trans-hexane $>1$-hexane (group II); heptane $>$ hexane $>$ pentane (group IV); and trichloroethylene $>$ methanol $>>$ acetone $>\mathrm{CH}_{2} \mathrm{Cl}_{2}$ (group V). Organic substances with long carbon chains readily succumbed to electron-beam treatment.

\subsubsection{Different base gas mixtures influence on the decomposition efficiency of aliphatic organic pollutants}

Won et al. (2002) studied TCE decomposition in different gas mixtures and found that the order of decomposition efficiency of TCE in different gas mixtures was: oxygen $>$ air $>\mathrm{H}_{2}>\mathrm{He}$.

\subsubsection{Water concentration}

In order to clarify $\mathrm{OH}$ radical influence on the chlorinated hydrocarbons (Cl-HC) decomposition, Won et al. (2002) tested TCE and PCE decomposition of air mixtures with different water vapor concentrations, and found that the decomposition efficiency of TCE and PCE increased less than $10 \%$ in the presence of water vapor compared with that in the dry air.

\subsubsection{Irradiation products}

The irradiation products of DCE, TCE and PCE in dry air under EB-irradiation were investigated by Won et al. (2002) and it was found that $\mathrm{CO}$ and $\mathrm{CO}_{2}$ were the irradiation products. For PCE, $\mathrm{CO}_{2}$ formation was above $40 \%$ at $15 \mathrm{kGy}$ absorbed dose. Vitale et al (1997a) also reported that $\mathrm{CO}, \mathrm{CO}_{2}$ and $\mathrm{HCl}$ as main irradiation products when they studied ethyl chloride and vinyl chloride decomposition in air. Prager et al. (1995) studied DCE, TCE and PCE degradation in dry or humidified synthetic air, they identified $\mathrm{HCl}, \mathrm{CO}$, chloromethanes, chloroacetyl chloride and phosgene as main products.

\subsection{Aliphatic organic pollutants degradation in batch system under EB-irradiation 3.2.1 Concentration of aliphatic organic pollutants vs. dose} Chloroethylene can be effectively decomposed by EB irradiation in the order of PCE > TCE > trans-DCE > cis-DCE (Hakoda et al., 1998a, 1998b, 1999, 2000, 2001; Hashimoto et al., 
2000). Sun et al. (2001, 2003) and Sun and Chmielewski (2004) studied 1,1-DCE, cis-DCE, trans-DCE decomposition under EB irradiation and found that the order of decomposition DCEs in air was 1,1-DCE > trans-DCE > cis-DCE. Decomposition efficiency of chloroethylene increases with the absorbed dose increase. The initial concentration of chlorinated ethylene was in below $2000 \mathrm{ppm}$ and the water concentration in the air mixture was 200-300 ppm. Son et al. (2010a) studied decomposition of butane in EB irradiation in batch system, it was found that removal efficiencies of butane were $40 \%$ at $2.5 \mathrm{kGy}$ and $66 \%$ at $10 \mathrm{kGy}$, when the initial concentration of butane was $60 \mathrm{ppm}$.

\subsubsection{Different base gas mixtures influence on the decomposition efficiency of aliphatic organic pollutants}

Different base gases influencing on the decomposition efficiency of butane were studied (Son et al, 2010a), it was found that decomposition efficiency of butane was extremely low when the background gas was He, in contrast to the efficiencies with background gases of $\mathrm{N}_{2}$ and air. Decomposition efficiencies of butane was $23 \%$ in $\mathrm{He}, 63 \%$ in $\mathrm{N}_{2}$ and $70 \%$ in air at 10 kGy absorbed dose.

\subsubsection{Water concentration}

Water influence on the TCE decomposition and irradiation products of TCE under EBirradiation were studied by Hakoda et al. (2000). It was found that when water concentration was below 1000 ppm, there was no big difference between process efficiency for dry and humid air for TCE decomposition and dichloroacetyl chloride, carbon monoxide, carbon dioxide, phosgene and small amount of chloroform irradiation products' formation.

This result agrees well with that water vapor effect on the TCE decomposition under EBirradiation in a flow system (Won et al., 2002). Sun et al. (2001) made a computer simulation of 1,1-DCE decomposition in air in a batch system and found that a reaction pathway of $\mathrm{OH}$ radical contributes less than $10 \%$ for 1,1-DCE decomposition. When water vapor concentration increased to $2.5 \%$, yield of gaseous products decreased, that means the aerosol products are possibly formed (Hakoda et al., 2000).

\subsubsection{Ozone}

Hakoda et al. $(1999,2000,2001)$ investigated $\mathrm{O}_{3}$ influence on the trans-DCE, cis-DCE and TCE decomposition by using EB-irradiation, it was found that $\mathrm{O}_{3}$ enhanced decomposition of trans-DCE only, cis-DCE and TCE were not affected.

\subsubsection{Irradiation products}

From environmental protection point of view, it is very important to identify by-products formation from Cl-HC degradation. Radiolytic products of trans-DCE, cis-DCE, TCE, PCE under EB-irradiation were reported by Hakoda et al. (1999, 2000, 2001). Chloroacetyl chloride and dichloroacetyl chloride were the main organic products for DCE (trans and cis) and TCE degradation; $\mathrm{CO}$ and $\mathrm{CO}_{2}$ were inorganic products and their formations were below $25 \%$ based on carbon balance. Chmielewski et al. (2004b), Sun et al. (2003) and Sun \& Chmielewski (2004) studied cis-DCE and trans-DCE degradation under EB-irradiation. Chloroacetyl chloride was not observed as degradation products, but it was a degradation product for 1,1-DCE (Sun et al., 2001). Son et al. (2010a) studied butane decomposition under EB irradiation and identified $\mathrm{CO}_{2}$, acetaldehyde, acetone, 2,3-butandione, 2-butanone, and 2-butanedinitrile as degradation products of butane. 


\subsection{Aromatic organic pollutants degradation in flow system under EB-irradiation}

In this section, besides aromatic chlorinated hydrocarbons degradation, decomposition of some nonchlorinated aromatic organic compounds will be discussed, too.

\subsubsection{Concentration of aromatic organic pollutants vs. dose}

Xylene and chlorobenzene decompositions in a flow system under EB-irradiation (Hirota et al. 2000, 2002) were studied, it was found that decomposition efficiency of xylene was higher than that of chlorobenzene, and about $50 \%$ chlorobenzene was decomposed at an absorbed dose of about $10 \mathrm{kGy}$ at the initial concentration of chlorobenzene being 10-40 ppm. Kim (2002) studied decomposition of benzene and toluene, it was found that the decomposition efficiency of toluene was higher than benzene, and about $80 \%$ benzene was decomposed at $16 \mathrm{kGy}$ when the initial concentration of benzene was smaller than or equal to $130 \mathrm{ppm}$. Han et al. (2003) studied toluene, ethylbenzene, o-, m-, p-xylenes and chlorobenzene decomposition in air. The order of the decomposition efficiency of selected VOCs from high to low was : toluene $>$ ethylbenzene $>$ benzene; p-xylene $>$ m-xylene $>$ o-xylene. About 44.7 $\%$ toluene and $43.2 \%$ ethylbenzene was decomposed at $10 \mathrm{kGy}$, while $85 \%$ chlorobenzene was decomposed. The decomposition efficiency of ethylbenzene and toluene was significantly increased about $50 \%$ with the addition of chlorobenzene comparing without chlorobenzene addition.

\subsection{2 $\mathrm{NH}_{3}$ influence on the decomposition efficiency of aromatic organic pollutants}

Effect of ammonia on the decomposition of PAHs was observed when an electron beam process was applied to treat multiple pollutants $\left(\mathrm{SO}_{2}, \mathrm{NOx}, \mathrm{PAHs}\right)$ with $\mathrm{NH}_{3}$ addition from industrial off-gases emitted from EPS, Kawęczyn, Poland (Chmielewski et al., 2002). $\mathrm{NH}_{3}$ addition enhanced PAHs removal efficiency. Hirota et al. (2000) studied chlorobenzene decomposition in air mixture, it was found that addition of $\mathrm{NH}_{3}$ enhanced the dechlorination of chlorobenzene. About $65 \%$ of chlorine in reacted chlorobenzene was dissociated from carbon with electron beam at doses of 4 and $8 \mathrm{kGy}$. Ammonia addition enhanced the dechlorination to $80 \%$.

\subsubsection{Water concentration}

Effect of water vapor on the decomposition of toluene was investigated by Kim (2002). It was found that the water vapor injection leads to $15-20 \%$ removal efficiency increase for toluene compared to the process without water injection. Water influences decomposition of toluene higher than TCE and PCE, $\mathrm{OH}$ radical plays an important role for aromatic hydrocarbon decomposition.

\subsubsection{Irradiation products}

Degradation products of chlorobenzene and xylene in an air mixture were studied by Hirota et al. (2000, 2002). The gaseous products of xylene degradation were identified to be formic, acetic, propionic, and butyric acids and/or the corresponding esters with $\mathrm{CO}$ and $\mathrm{CO}_{2}$. Approximately $30 \%$ of the reacted xylene was the gaseous products at a dose of $8 \mathrm{kGy}$. Organic and inorganic chlorine presence in gaseous, aerosols and residues were investigated by same authors for chlorobenzene degradation. Inorganic chlorine was mainly presented in gaseous products, while organic chlorine was presented in aerosols and residues aerosols and residues. Some aerosol products were formed from chlorobenzene degradation, and $3 \%$ of the 
aerosol products were identified to be carboxylic acids or esters (Hirota et al., 2000). Aerosols, benzaldehyde, dipropyl 1,2-benzenedicarboxylic acid, nitromethane were reported as toluene main degradation products in dry air under EB irradiation; while methyl chloride, dipropyl 1,2-benzenedicarboxylic acid, toluene, nitromethane were reported as main degradation products of ethylbenzene/chlorobenzene mixture in dry air. Trace amount of acetone, hexane, benzene was also observed (Han et al., 2003).

\subsection{Aromatic organic pollutants degradation in batch system under EB-irradiation 3.4.1 Concentration of aromatic organic pollutants vs. dose}

Decomposition of aromatic organic compounds in a batch system vs. dose under EBirradiation was studied by Hirota et al. (2002, 2004), Ostapczuk et al.(1999), Sun et al. (2008) and Hashimoto et al. (2000). Decomposition efficiency of these compounds increase with the absorbed dose increase, 4-chlorotoluene (4-CTO) decomposition as an example was presented in Fig. 1 . The order of decomposition efficiency of these compounds was: xylene $>$ chlorobenzene $>$ benzene $>$ hexane $>$ cyclohexane. For 4-chlorotolunene (4-CTO) and 1,4dichlorobenzene (1,4-DCB), no apparent decomposition efficiency of these two compounds was observed (Fig.2).

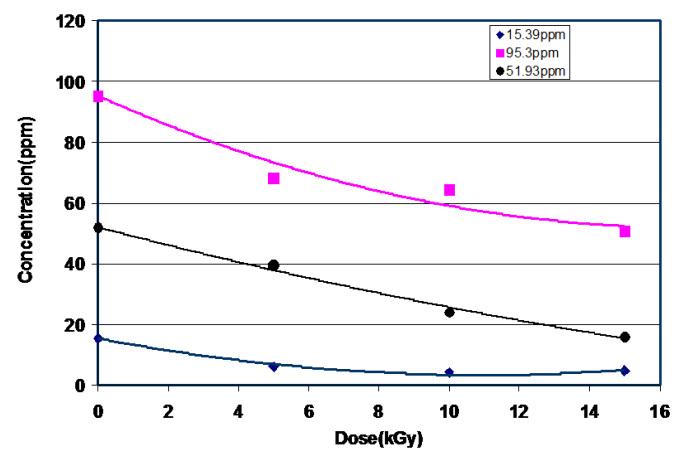

Fig. 1. 4-Chlorotoluene decomposition in air mixture in an electron beam generated nonthermal reactor.

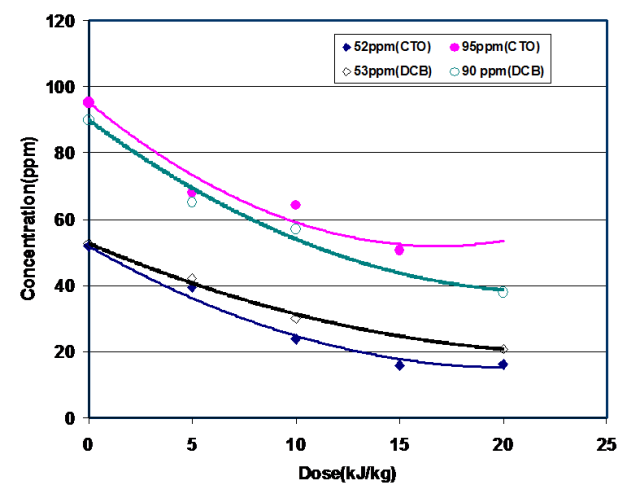

Fig. 2. Decomposition efficiency comparison between 4-chlorotoluene and 1,4dichlorobenzene. 
The decomposition efficiency of chlorinated aliphatic hydrocarbons using EB irradiation is more efficient than that of chlorinated aromatic hydrocarbons. $25.0 \mathrm{kGy}$ is sufficient to remove over 97\% 1,1-DCE and $98.0 \%$ trans-DCE at initial concentration of 1,1-dichloroethylene (DCE) and trans-dichloroethylene being $903.8 \mathrm{ppm}$ and $342.0 \mathrm{ppm}$, respectively; while $60 \%$ 1,4-dichlorobenzene (DCB) at intial concentration being 90ppm was removed at $57.9 \mathrm{kGy}$. This result is comparable with decomposition of chlorobenzene. Hakoda et al. (1998b) and Hashimoto et al. (2000) studied degradation of chlorobenzene/air using EB irradiation in batch system, it was found that $40 \%$ chlorobenzene was removed under EB-irradiation at 37.7 kGy dose (calculated by $\mathrm{N}_{2} \mathrm{O}$ gas dosimeter) for initial concentration of chlorobenzene being $102 \mathrm{ppm}$. Sun et al. (2007a) studied 1-chloronaphathalene and found that over $80 \%$ 1-chloronapthalene was removed at 57.9 kGy under EB-irradiation for low initial concentration of 1-chloronaphthalene (12 30 $\mathrm{mg} / \mathrm{m}^{3}$ ) in air mixture. Energy consumption for decomposition 1,4-dichlorobenzene was lower than that of 1-chloronaphthalene. Therefore, the observed order in easily decomposition chlorinated hydrocarbons is: 1,1-DCE > trans-DCE > cis-DCE >1,4-DCB > 1-chloronaphthalene. Based on this work and other's work, we learn that: For chlorinated aliphatic hydrocarbons, the more chlorinated compounds is, the more it is easy to be decomposed.

Aliphatic hydrocarbons is more easily decomposed than aromatic hydrocarbons. For aromatic hydrocarbons, compounds with less benzene ring are easily to be decomposed.

\subsubsection{Different base gas mixtures influence on the decomposition efficiency of aromatic organic pollutants}

Toluene decomposition at different background gases in a batch system was studied by Kim (2002). The order of decomposition efficiency of toluene in different background gases is: $\mathrm{N}_{2}$ $>$ air $>\mathrm{O}_{2}>\mathrm{He}$. This order is different from the order for TCE decomposition in a flow system (Won et al., 2002).

We studied 1,4-dichlorobenzene (1,4-DCB) decomposition in different base gas mixtures at the initial concentration of 1,4-DCB being $50 \mathrm{ppm}$, the similar phenomenon was observed (Sun et al, 2006). The decomposition efficiency of 1,4-DCB in nitrogen is higher than that in air and much more higher than in $1.027 \%$ NO- $\mathrm{N}_{2}$ mixture( $\mathrm{N}_{2}$ as balance gas) (Fig.3), this phenomenon agrees well with toluene decomposition in different gases (Kim, 2002).

\subsubsection{Water concentration}

Effect of water vapor on the decomposition of aromatic compounds in a batch system under EB-irradiation was investigated by Kim (2002). Four percent water vapor injection leads to $5-10 \%$ increase of VOC removal efficiency for both toluene and benzene, and effect of water vapor influence on the decomposition of toluene under EB irradiation in a flow system is higher than that in a batch system.

\subsubsection{Irradiation products}

Benzaldehyde and phenol were reported as products when Ostapczuk et al. (1999) studied styrene decomposition in air under EB irradiation, the removal efficiency of styrene was ranged from $83-95 \%$. The humidity in air mixture was ranged from $0.3 \%$ to $1.6 \%$. In order to obtain information of by-products produced from toluene destruction, we carried out experiment at higher inlet concentration of toluene at higher absorbed dose. More than $97 \%$ 
toluene was removed from gas phase at $53.6 \mathrm{kGy}$ absorbed dose when inlet concentration of toluene was $151.9 \mathrm{ppm}$. A GC-MS spectrum of toluene/air mixture after EB-irradiation is presented in figure 4. A trace amount of benzaldehyde was eluted at retention time 7.735 min in figure 4 and was identified by our carefully comparing mass spectrum of this compound with a reference mass spectrum of benzaldehyde provided by Wiley library (figures $5 \mathrm{a} \& 5 \mathrm{~b}$ ). Trace amount acetone was also found in our experimental condition (Sun et al., 2009a).

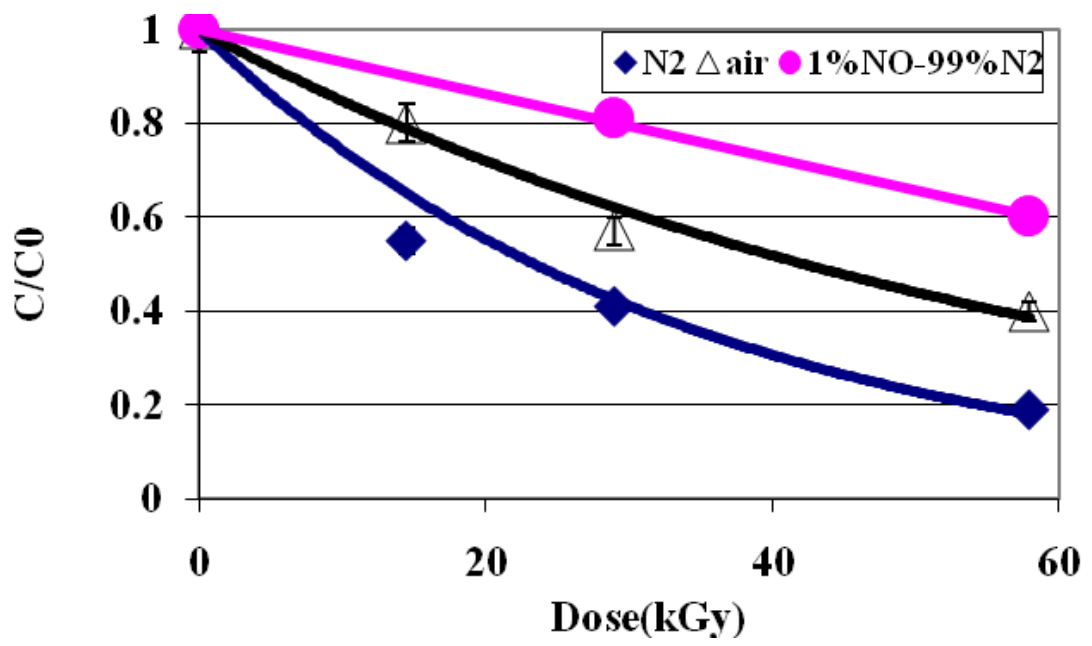

Fig. 3. 1,4-Dichlorobenzene decomposition in different gas mixture

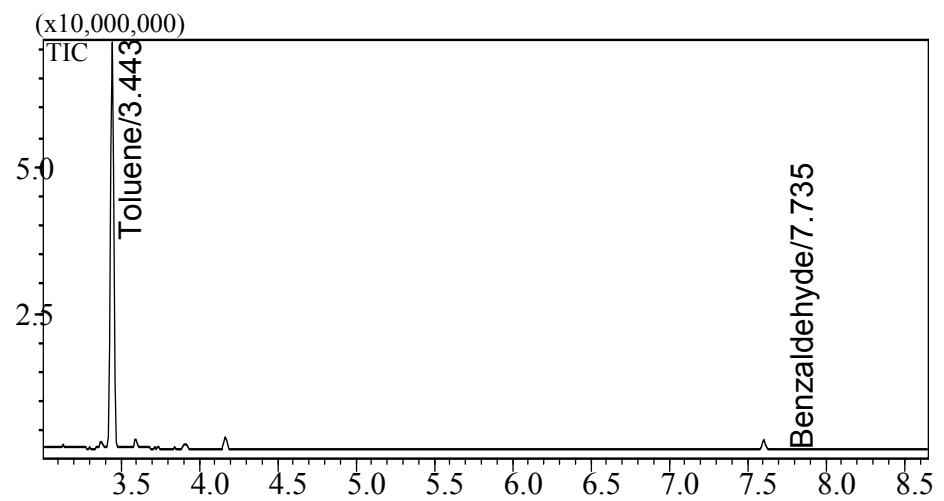

Fig. 4. A GC-MS spectrum of toluene/air mixture after EB-irradiation (inlet concentration of toluene was $151.9 \mathrm{ppm}$, dose was $53.6 \mathrm{kGy}$ ).

Benzaldehyde as by-product of degradation of toluene was also reported(Han et al., 2003; Kim et al., 2005). Trace amount of acetone was found based on Han et al.'s work (2003). Besides these, Aerosols and benzene were reported as by-products in both works (Han et al., 
2003; Kim et al., 2005). Han et al.(2003) also identified dipropyl 1,2-benzenedicarboxylic acid, nitromethane and trace amount of hexane as by-products of degradation of toluene. For degradition of 4-chlorotoluene in air mixture, chlorobenzene $\left(\mathrm{C}_{6} \mathrm{H}_{5} \mathrm{Cl}\right.$, retention time was $4.910 \mathrm{~min})$ and 4-chlorobenzaldehyde $\left(\mathrm{ClC}_{6} \mathrm{H}_{4} \mathrm{CHO}\right.$, retention time was $\left.12.502 \mathrm{~min}\right)$ were identified as by-products. A GC-MS spectrum of 4-chlorotoluene/air mixture after EBirradiation was presented in figure 6, a compound eluted at retention time $7.590 \mathrm{~min}$ of the GC-MS spectrum was identified as 4-chlorotoluene (Sun et al., 2008).

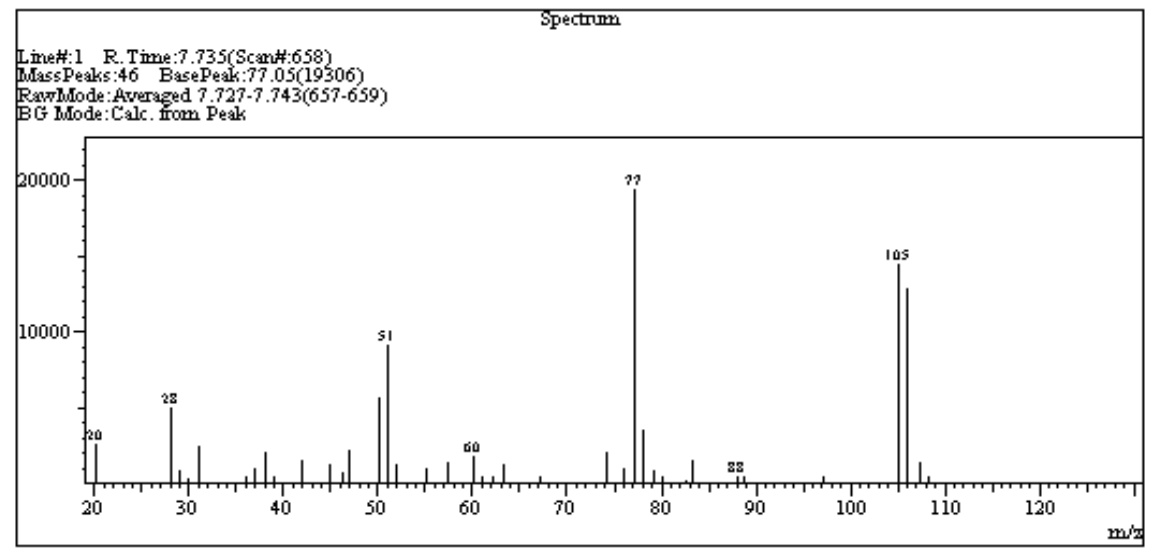

Fig. 5a. A mass spectrum of by-product which eluted at 7.735 min retention time

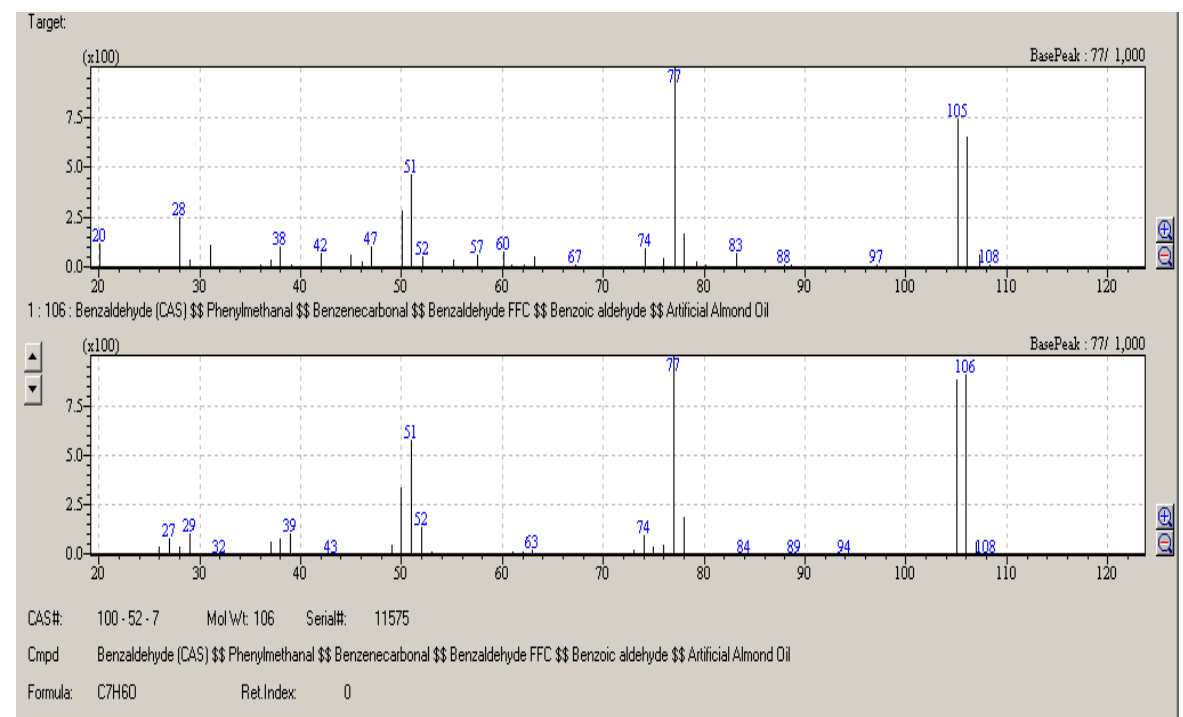

Fig. 5b. A mass spectrum of the compound which eluted at 7.735 min retention time and its reference mass spectrum of benzaldehyde 


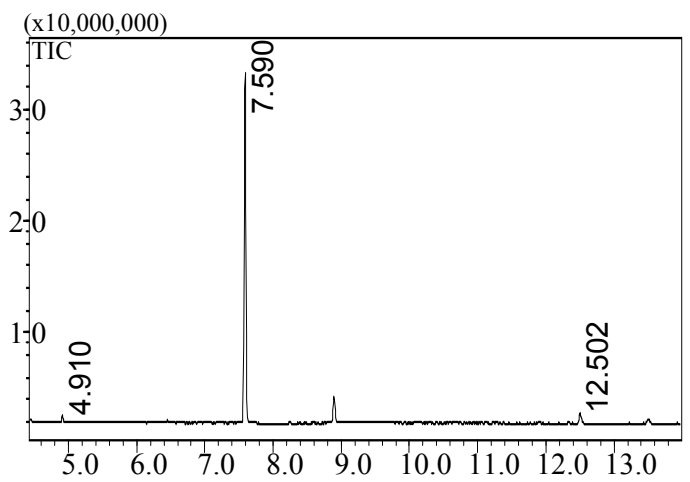

Fig. 6. A GC-MS spectrum of 4-chlorotoluene/air mixture after EB-irradiation

\subsection{PAHs and Dioxin removal from waste off-gas under EB-irradiation}

Dioxins reduction from waste incinerator was studied using EB technology in Japan (Hirota et al., 2003) and in Germany (Paur et al., 1998). Hirota et al. (2003) studied reduction the emission of polychlorinated dibenzo- p-dioxins (PCDD) and polychlorinated dibenzofurans (PCDF) in a flue gas of $1000 \mathrm{~m}^{3} \mathrm{~N} / \mathrm{h}$ from the municipal solid waste incinerator (MSWI), located at Takohama Clean Center which treats $450 \mathrm{t}$ (150 $\mathrm{t} * 3$ furnaces) of solid waste in 1 day, at a temperature of $200{ }^{\circ} \mathrm{C}$. they found that more than $90 \%$ PCDD/Fs was removed at $14 \mathrm{kGy}$ when initial concentration of PCDD was in the range of $0.22-0.88 \mathrm{ng}-\mathrm{TEQ} / \mathrm{m}^{3} \mathrm{~N}$ and PCDF in the range of $0.35-12.4 \mathrm{ng}-\mathrm{TEQ} / \mathrm{m}^{3} \mathrm{~N}$. Paul et al. (1998) also reported that over $90 \%$ PCDD was removed at $12 \mathrm{kGy}$ dose for inital concentration of PCDD being $21-110 \mathrm{ng} / \mathrm{m}^{3} \mathrm{~N}$ (AGATE-M plant, Germany).

16 kinds of toxic PAHs were investigated under electron beam irradiation in the pilot plant in Electric Power Station Kawęczyn, Poland (Chmielewski, et al., 2003). The investigation was carried out under the following experimental conditions: flue gas flow rate $5000 \mathrm{Nm}^{3} / \mathrm{h}$; humidity $4.5 \%$; inlet concentrations of $\mathrm{SO}_{2}$ and $\mathrm{NOx}$ that were emitted from the power station were 192 and 106 ppm, respectively; ammonia addition was $2.75 \mathrm{Nm}^{3} / \mathrm{h}$; alcohol addition was 600 l/h, the absorbed dose was 8 kGy. The results was presented in Fig.7. It was found that under these experimental conditions the concentrations of naphthalene ( $\mathrm{NL}, \mathrm{C}_{10} \mathrm{H}_{8}$ ), acenaphthene $\left(\mathrm{AC}, \mathrm{C}_{12} \mathrm{H}_{10}\right)$, fluorene $\left(\mathrm{C}_{13} \mathrm{H}_{10}\right)$, phenanthrene $\left(\mathrm{C}_{14} \mathrm{H}_{10}\right)$, anthracene $\left(\mathrm{C}_{14} \mathrm{H}_{10}\right)$ were decreased, while the concentrations of acenaphthylene $\left(\mathrm{C}_{12} \mathrm{H}_{8}\right)$, fluoranthene $\left(\mathrm{C}_{16} \mathrm{H}_{10}\right)$, pyrene $\left(\mathrm{C}_{16} \mathrm{H}_{10}\right)$, benzo(a)anthracene $\left(\mathrm{C}_{18} \mathrm{H}_{12}\right)$, chrysene $\left(\mathrm{C}_{18} \mathrm{H}_{12}\right)$, benzo $\left(\mathrm{b} \mathrm{p}\right.$ k)fluoranthene $\left(\mathrm{C}_{20} \mathrm{H}_{12}\right)$, benzo(e)pyrene $\left(\mathrm{C}_{20} \mathrm{H}_{12}\right)$, benzo(a)pyrene $\left(\mathrm{C}_{20} \mathrm{H}_{12}\right)$, perylene $\left(\mathrm{C}_{20} \mathrm{H}_{12}\right)$, dibenzo(a; h)anthracene+indeno $(1,2,3-c d)$ pyrene $\left(\mathrm{C}_{22} \mathrm{H}_{14}\right)$, benzo $\left(\mathrm{g}\right.$; $\mathrm{h}$; l)perylene $\left(\mathrm{C}_{22} \mathrm{H}_{12}\right)$ were increased. Removal efficiencies of $\mathrm{SO}_{2}$ and $\mathrm{NOx}$ were $61.6 \%$ and $70.9 \%$, respectively. The concentration of hydrocarbons of small aromatic ring (PAHs, like naphthalene $\left(\mathrm{C}_{10} \mathrm{H}_{8}\right)$, acenaphthene $\left(\mathrm{C}_{12} \mathrm{H}_{10}\right)$, fluorene $\left(\mathrm{C}_{13} \mathrm{H}_{10}\right)$, anthracene $\left.\left(\mathrm{C}_{14} \mathrm{H}_{10}\right)\right)$ was reduced, while the concentration of fluoranthene was increased remarkably after irradiation.

Similar experiments were carried out in EPS Kawęczyn with ammonia presence but without alcohol addition (Chmielewski et al, 2002; Ostapczuk et al, 2008a). It was found that removal efficiency of PAHs ranges from $40 \%$ up to $98 \%$.

Callén et al. (2007) studied PAH removal from lignite-combustion flue gas from Bulgarian Maritza-East thermal power plant (TPP) and obtained that PAHs concentration after EB 
irradiation resulted in $\sim 10$ fold decrease in studied PAHs emissions. The removal efficiency of $\mathrm{PAH}$ removal at the dose of $4 \mathrm{kGy}$ was $85 \%$ (weight/weight). High PAH removal efficiency was obtained especially for 2 and 3 rings $\mathrm{PAH}$, this result was similar to that obtained in our previous work (Chmielewski et al., 2003).

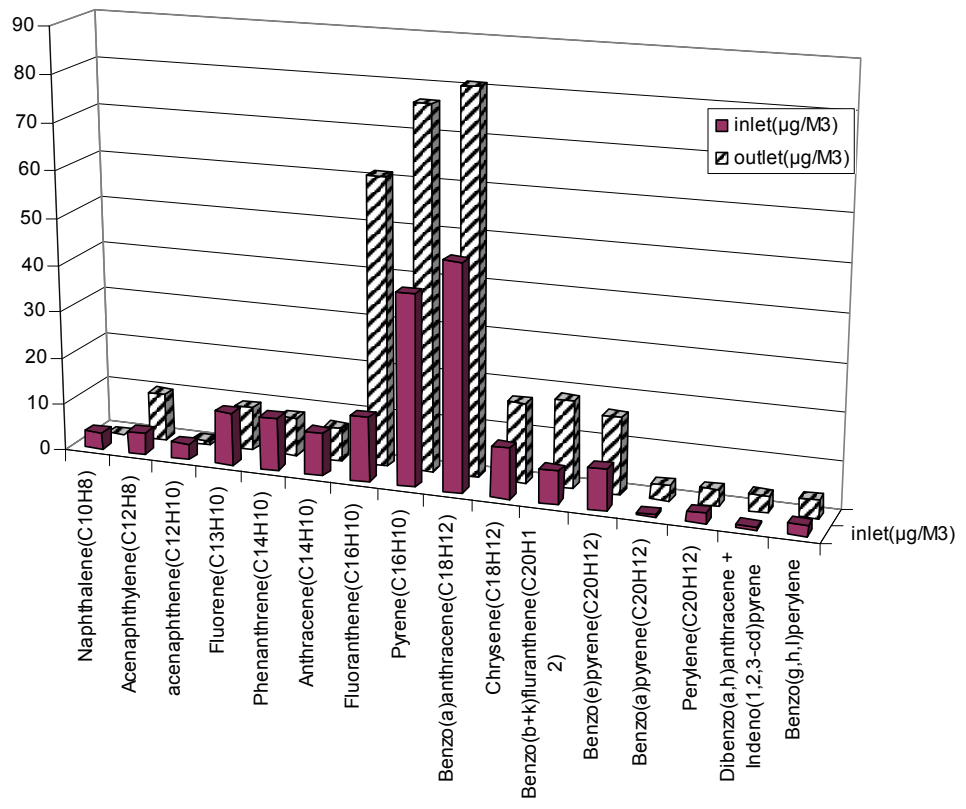

Fig. 7. EB irradiation influence on PAHs removal.

The concentration of PAHs in by-product was also examined. It was relatively low, varied from few up to $12 \mu \mathrm{g}$ per $\mathrm{kg}$ of fertilizer for the experimental work carried out in EPS Kawęczyn, Poland. Less than 3\% of PAH were removed in adsorption on the by-product surface (Ostapczuk, et al., 2008a). The study in Maritza-East TPP allowed PAH assessment in solid by-products obtained from EB lignite-combustion flue gas. The determined PAH content was reasonable, $\sim 60 \mathrm{microg} / \mathrm{kg}$ and was lower than PAHs background in Bulgarian soils. These results demonstrated the insignificant role of adsorption for PAHs removal (Callén et al., 2007).

Naphthalene (NL) and acenaphthene (AC) decomposition in gas mixture was studied in lab scale experiment (Ostapczuk, et al., 2008b). It was found that NL was more easily decomposed than AC, G-values for these two compounds were 1.66 and $3.72 \mathrm{~mol} / 100 \mathrm{eV}$ for NL and AC at the dose of $1 \mathrm{kGy}$, respectively. Humidity influencing on NL and AC decomposition was studied. About $26 \%$ and $50 \%$ NL were decomposed at $1 \mathrm{kGy}$ dose in dry air (90 vol\% $\mathrm{N}_{2} ; 10 \mathrm{vol} \% \mathrm{O}_{2}$ and $\left.160 \mathrm{ppmv} \mathrm{NO}\right)$ and in humid air (84 vol\% $\mathrm{N}_{2} ; 10 \mathrm{vol} \% \mathrm{O}_{2}$ and $6 \mathrm{vol} \% \mathrm{H}_{2} \mathrm{O}$ ), respectively. NL concentration in both mixtures was on the level of 10-11 ppmv. For $\mathrm{AC}$, about $45 \%$ (in $\mathrm{O}_{2}$ ) and $82 \% \mathrm{AC}$ (in humid $\mathrm{O}_{2}, 94 \% \mathrm{O}_{2}+6 \% \mathrm{H}_{2} \mathrm{O}$ ) were decomposed at $1 \mathrm{kGy}$ dose for the initial concentration of AC being $160 \mathrm{ppm}$. Two-ringed naphthol and nitronaphthalene; one-ringed 2,6-dietylbenzoquinone, indane, 1,2- and 1,4dimetoxybenzenes and carbon oxides were identified as by-products of NL decomposition. 


\section{A novel hybrid EB-catalyst technology to treat organic pollutants}

Electron beam (EB) irradiation is one of the most promising technologies for purification of dilute pollutants, mostly VOCs, with high flow-rate gas stream released from industrial offgases. Under EB irradiation, VOCs are oxidized into irradiation by-products as well as $\mathrm{CO}_{2}$ and $\mathrm{CO}$. However, some of these irradiation by-products have adverse effect on environment and human beings.

A new technology which combines EB and catalyst together to treat aromatic VOCs, e.g., toluene (Kim et al., 2004, 2005; Jeon et al., 2008) styrene(Kim, 2005) , o-Xylene (Hakoda et al., 2008a, 2008b) and ethylbenzene (Son, et al, 2010b) was developed in the aim of enhancing higher oxidation efficiencies of VOCs into $\mathrm{CO}_{2}$. Removal efficiency of toluene, styrene and ethylbenzene increased by $10 \%, 20 \%$, and $20 \%$ in an EB-catalyst hybrid system in comparison with that achieved in catalyst-only method at approximately $10 \mathrm{kGy}$ absorbed dose (Kim, et al, 2005). Removal efficiency of ethylbenzene in the EB-catalyst hybrid was $30 \%$ higher than that of EB-only treatment. Ethylbenzene was decomposed more easily than toluene by EB irradiation. The G-values for ethylbenzene increased with initial concentration and reactor type: the G-values vary in the range of 7.5-10.9 (EB-only) and 12.925.7 (EB-catalyst hybrid) by reactor type at the initial concentration of ethylbenzene being $2800 \mathrm{ppm}$. Son et al. (2008) and Jeon et al. (2008) also studied different catalysts (Pt, Pd , Cu and $\mathrm{Mn}$ ) and humidity influence on removal efficiency of toluene using EB-catalyst hybrid system. It was found that removal efficiency of toluene was increased by $36.9 \%, 35.3 \%$ and $22 \%$ in the presence of $\mathrm{Pt}, \mathrm{Pd}, \mathrm{Mn}$ and $\mathrm{Cu}$ catalysts comparing with $\mathrm{EB}$ only for initial concentration of toluene being $1500 \mathrm{ppm}$, the selectivity to $\mathrm{CO}_{2}$ with $\mathrm{Pt}$ and $\mathrm{Pd}$ coupling were relatively higher than those of $\mathrm{Cu}$ and $\mathrm{Mn}$. Especially the $\mathrm{CO}_{2}$ selectivity of EB-Pt coupling was significantly high at a relatively low absorbed dose. The catalytic activity for EB-catalyst coupling system was in the order of $\mathrm{Pt}, \mathrm{Pd}, \mathrm{Mn}$ and $\mathrm{Cu}$. There was no significant difference of removal efficiency of toluene among $0.1,0.5$ and $1.0 \mathrm{wt} \%$ loading of catalyst. No significant water effect was observed in EB-catalyst hybrid system (Son et al, 2008).

Other type of catalysts such as $\mathrm{TiO}_{2}$ (Hakoda, et al., 2008a) was used to study xylene decomposition under EB irradiation in lab scale experimental work. It was found that removal efficiency of xylene and $\mathrm{CO}_{2}$ formation were increased with the presence of $\mathrm{TiO}_{2}$ catalyst, the similar phenomenon was observed when Kim studied toluene decomposition using Pt as catalyst (Kim et al., 2005).

Hakoda, et al.(2008b) also studied xylene decomposition using $\mathrm{MnO}_{2}\left(\right.$ an $\mathrm{O}_{3}$ decomposition catalyst), $\gamma-\mathrm{Al}_{2} \mathrm{O}_{3}$ was selected as a base material of the catalyst. The combination process at temperatures of about $100^{\circ} \mathrm{C}$ using $\mathrm{MnO}_{2}$ placed downstream enhanced the oxidation of the by-products of xylene into $\mathrm{CO}_{2}$ by active oxygen produced from the $\mathrm{O}_{3}$ decomposition when the $\mathrm{MnO}_{2}$ bed was placed downstream of an irradiation space. Furthermore, EB-irradiated $\gamma-\mathrm{Al}_{2} \mathrm{O}_{3}$ surface was found to be active, and the oxidation of organics was enhanced by primary electrons. The combination process using $\mathrm{\gamma}-\mathrm{Al}_{2} \mathrm{O}_{3}$ reduced dose to $33 \%$ of a single EB process to obtain the same conversion of xylene to $\mathrm{CO}_{2}$.

Ighigeanu (et al., 2008) studied VOCs (Toluene, hexane + toluene mixture diluted in air) decomposition by using combination of three different technologies (EB, microwave (MW) and catalysts): $(\mathrm{EB}+\mathrm{MW}+$ catalyst); (MW + catalyst) and (EB+catalyst). They found that decomposition efficiency (De) and oxidation efficiency (Eo) of toluene increased significantly for the (EB+MW+catalyst) treatment as compared with (MW + catalyst) and $(\mathrm{EB}+$ catalyst) treatments, at initial concentration of toluene being in the range of $180 \mathrm{ppm}-$ 
523 ppm; and $\mathrm{CO}_{2}$ and $\mathrm{CO}$ concentrations after treatment were higher for the $(\mathrm{EB}+\mathrm{MW}+$ catalyst) treatment than for $(\mathrm{MW}+$ catalyst) and (EB+catalyst) treatments. De and Eo of toluene were, respectively, as follows: $59.5 \%$ and $82.2 \%$ for the (MW + catalysis), $77.2 \%$ and $87.1 \%$ for the (EB + catalyst) and $92.8 \%$ and $90.5 \%$ for the( EB + MW + catalyst). For air mixture contained toluene and hexane, removal efficiency of toluene and hexane in (EB + $\mathrm{MW}+$ catalyst) system was higher than that in (MW + catalyst) system or in (EB + catalyst) system, about $88.5 \%$ toluene and $87.8 \%$ hexane were decomposed for initial toluene and hexane concentration being $250 \mathrm{ppm}$, respectively.

\section{Mechanism of organic pollutants degradation by using EB technology}

In order to obtain high decomposition efficiency of organic pollutants and less toxic byproducts, it is very important to understand mechanism of organic pollutants degradation under EB irradiation. In this section, we will discuss mechanism of two groups (chlorinated and nonchlorinated) organic pollutants. General mechanism of organic pollutants decomposition in gas phase under EB irradiation is illustrated in Fig. 8.

EB

Base gas

e, ions, radicals etc.

Pollutants $\longrightarrow \mathrm{CO}_{2}$, other by-products

Fig. 8. General mechanism of organic pollutants decomposition under EB irradiation

5.1 Chlorinated organic compounds (CI-HC)

5.1.1 General mechanism of chlorinated aliphatic hydrocarbon decomposition in air mixture

Computer simulations of chlorinated aliphatic hydrocabons'decomposition in air mixture were carried out and discussed in details (Nichipor et al., 2000, 2002, 2003, 2008; Sun et al., $2001,2007 b, 2009 b)$. The general mechanism of aliphatic hydrocarbon decomposition in an air mixture is described below:

When fast electrons from electron beams are absorbed in the carrier gas, they cause ionization and excitation processes of the nitrogen, $\mathrm{H}_{2} \mathrm{O}$ and oxygen molecules in the carrier gas. Primary species and secondary electrons are formed. The secondary electrons are thermalized fast within $1 \mathrm{~ns}$ in air at 1 atmosphere .

The G-values (molecules/100 eV) of main primary species are simplified as follows (Mätzing, 1989):

$$
\begin{gathered}
4.43 \mathrm{~N}_{2} \rightarrow 0.29 \mathrm{~N}_{2}{ }^{*}+0.885 \mathrm{~N}\left({ }^{2} \mathrm{D}\right)+0.295 \mathrm{~N}(2 \mathrm{P})+1.87 \mathrm{~N}+2.27 \mathrm{~N}_{2}{ }^{+}+0.69 \mathrm{~N}^{+}+2.96 \mathrm{e} \\
5.377 \mathrm{O}_{2} \rightarrow 0.077 \mathrm{O}_{2}{ }^{*}+2.25 \mathrm{O}\left({ }^{1} \mathrm{D}\right)+2.8 \mathrm{O}+0.18 \mathrm{O}^{*}+2.07 \mathrm{O}_{2}{ }^{+}+1.23 \mathrm{O}^{+}+3.3 \mathrm{e} \\
\begin{array}{c}
7.33 \mathrm{H}_{2} \mathrm{O} \rightarrow 0.51 \mathrm{H}_{2}+0.46 \mathrm{O}\left({ }^{3} \mathrm{P}\right)+4.25 \mathrm{OH}+4.15 \mathrm{H}+1.99 \mathrm{H}_{2} \mathrm{O}^{+}+0.01 \mathrm{H}_{2}{ }^{+}+0.57 \mathrm{OH}^{+} \\
+0.67 \mathrm{H}^{+}+0.06 \mathrm{O}^{+}+3.3 \mathrm{e}
\end{array}
\end{gathered}
$$


Where G-values of molecules decomposed are listed in the left side of the arrows, and Gvalues of species formed from the pure $\mathrm{k}$ type molecules that absorb an energy of $100 \mathrm{eV}$ are listed in the right side of the arrows. These primary species and thermalized secondary electrons cause $\mathrm{Cl}-\mathrm{HC}$ decomposition. Based on our and others published work, we know that several type reactions cause $\mathrm{Cl}-\mathrm{HC}$ degradation.

\section{Positive ions charge transfer and particle dissociation reactions}

It is well known that : when air component and molecule are ionized and excited, a large amount of $\mathrm{N}_{2}{ }^{+}, \mathrm{O}_{2}{ }^{+}, \mathrm{N}^{+}, \mathrm{O}^{+}, \mathrm{H}_{3} \mathrm{O}^{+}$( if water concentration is high) are formed, and their ionization potential energy (IE) is higher than that of $\mathrm{Cl}-\mathrm{HC}$ (see Table 2). The positive charge transfer reaction, positive ion cluster reaction, or particle dissociation reaction occur (Spanel, et al., 1999a, 1999b).

\begin{tabular}{|l|l|l|l|}
\hline Molecule & IE(eV) & EA(eV) & PA(kJ.mol-1) \\
\hline $\mathrm{N}_{2}$ & 15.58 & & 493.8 \\
\hline $\mathrm{O}_{2}$ & 12.07 & 0.45 & 421 \\
\hline $\mathrm{H}_{2} \mathrm{O}$ & 12.62 & & 691 \\
\hline $\mathrm{NO}$ & 9.26 & 0.03 & 531.8 \\
\hline $\mathrm{O}_{3}$ & 12.53 & 2.10 & 625.5 \\
\hline $\mathrm{CCl}_{4}$ & 11.47 & 0.80 & \\
\hline $\mathrm{CHCl}_{3} \mathrm{CH}_{2} \mathrm{ClCH}_{2} \mathrm{Cl}$ & 11.37 & 0.62 & 650.6 \\
\hline $\mathrm{CHCl}_{2} \mathrm{CH}_{3}$ & 11.07 & & \\
\hline $\mathrm{C}_{2} \mathrm{H}_{3} \mathrm{Cl}^{1,1-\mathrm{C}_{2} \mathrm{H}_{2} \mathrm{Cl}_{2}}$ & 11.04 & & \\
\hline cis- $\mathrm{C}_{2} \mathrm{H}_{2} \mathrm{Cl}_{2}$ & 9.99 & & \\
\hline trans- $\mathrm{C}_{2} \mathrm{H}_{2} \mathrm{Cl}_{2}$ & 9.81 & 0.1 & \\
\hline $\mathrm{C}_{2} \mathrm{HCl}_{3}$ & 9.65 & & \\
\hline $\mathrm{C}_{2} \mathrm{Cl}_{4}$ & 9.64 & & \\
\hline $1,4-$ dichlorobenzene & 9.46 & 0.40 & \\
\hline
\end{tabular}

Table 2. Ionization energy (IE,eV), electron affinity $(\mathrm{EA}, \mathrm{eV})$ and proton affinity $\left(\mathrm{PA}, \mathrm{kJ}^{\mathrm{m}} \mathrm{mol}^{-1}\right)$ data.

In general, the $\mathrm{H}_{3} \mathrm{O}^{+}$reactions with the aliphatic chloride more varies in their rate constants and products, and in some reactions $\mathrm{H}_{3} \mathrm{O}^{+}$. M ions $(\mathrm{M}=\mathrm{Cl}-\mathrm{HC})$ are formed. The $\mathrm{NO}^{+}$reaction with the aliphatic compounds is generally slow association reactions and form $\mathrm{NO}^{+} . \mathrm{M}$ ions (for e.g., $\mathrm{NO}^{+}+\mathrm{CHClCCl}_{2}=\mathrm{NO}^{+} . \mathrm{CHClCCl}_{2}$ ). The $\mathrm{O}_{2}{ }^{+}$reactions are fast mainly proceeding via nondissociative charge transfer reactions to produce the cations $\mathrm{M}^{+}$ only (for e.g., $\mathrm{C}_{2} \mathrm{HCl}_{3}+\mathrm{O}_{2}{ }^{+}=\mathrm{C}_{2} \mathrm{HCl}_{3}{ }^{+}+\mathrm{O}_{2}$ ), but in some of these reactions minority dissociative charge transfer reactions take place to eliminate $\mathrm{Cl} / \mathrm{HCl}$ and leave hydrocarbon ion (for e.g., $\mathrm{CH}_{2} \mathrm{ClCH}_{2} \mathrm{Cl}+\mathrm{O}_{2}{ }^{+}=\mathrm{C}_{2} \mathrm{H}_{3} \mathrm{Cl}^{+}(95 \%)+\mathrm{HCl}+\mathrm{O}_{2}$; and $\mathrm{CH}_{2} \mathrm{ClCH}_{2} \mathrm{Cl}$ $\left.+\mathrm{O}_{2}{ }^{+}=\mathrm{C}_{2} \mathrm{H}_{4} \mathrm{Cl}^{+}(5 \%)+\mathrm{Cl}+\mathrm{O}_{2}\right)$.

From the calculation results of dichloroethylene (Sun et al., 2001, 2007b), trichloroethylene (Nichipor et al, 2008) and tetrachloroethylene (Sun et al, 2009b), we learn that positive charge transfer reactions contributing to chlorinated ethylenes decomposition less than $10 \%$ 


\section{Secondary electron attachment, $\mathrm{Cl}$ dissociated reaction and negative ions charge transfer} reactions

Reaction pathway of secondary electron attachment, $\mathrm{Cl}$ dissociative reactions followed by peroxyl radical reactions is the main reaction pathway which causes $\mathrm{Cl}-\mathrm{HC}$ decomposition. The rate constants of electron and $\mathrm{Cl}$ with $\mathrm{Cl}-\mathrm{HC}$, and the products of these reactions are listed in table 3, respectively (Atkinson, R., 1987a).

For chlorinated methane, the products formed by $\mathrm{Cl}$ with $\mathrm{CH}_{3} \mathrm{Cl}, \mathrm{CH}_{2} \mathrm{Cl}_{2}, \mathrm{CHCl}_{3}$, reactions are: $\mathrm{CH}_{2} \mathrm{Cl}, \mathrm{CHCl}_{2}, \mathrm{CCl}_{3}$, and $\mathrm{HCl}$; for chlorinated methane $\mathrm{CCl}_{4}, \mathrm{CCl}_{3}$ and $\mathrm{Cl}_{2}$ are formed.

If we assume $\mathrm{CH}_{2} \mathrm{Cl}, \mathrm{CHCl}_{2}, \mathrm{CCl}_{3}$ as radical $\mathrm{R}$, generalized mechanism of peroxyl radical reactions could be written as follows:

$$
\begin{gathered}
\mathrm{R}+\mathrm{O}_{2}=\mathrm{RO}_{2} \\
\mathrm{RO}_{2}+\mathrm{RO}_{2}=2 \mathrm{RO}+\mathrm{O}_{2} \\
\mathrm{RO}=\text { products }
\end{gathered}
$$

This is a main reaction pathway for Cl-HC decomposition (Bryukov et al., 2002;).

For chlorinated aliphatic ethylene, the mechanism of its degradation in air mixture can be generalized as follows:

$$
\begin{gathered}
\mathrm{e}+\mathrm{C}_{2} \mathrm{X}_{3} \mathrm{Cl}=\mathrm{Cl}^{-}+\bullet \mathrm{C}_{2} \mathrm{X}_{3} \text { (Szamrej, et al., 1996; ) } \\
\mathrm{X}_{2} \mathrm{CCX}_{2}(\mathrm{X}=\mathrm{H}, \mathrm{Cl} \text {, at least } 1 \mathrm{Cl} \text { inside) } \\
\mathrm{X}_{2} \mathrm{CCX}_{2}+\mathrm{Cl} \rightarrow(\mathrm{Cl}) \mathrm{X}_{2} \mathrm{CCX}_{2}(\mathrm{Cl} \text { adds to heavily chlorinated carbon side) } \\
(\mathrm{Cl}) \mathrm{X}_{2} \mathrm{CCX}_{2}+\mathrm{O}_{2} \rightarrow(\mathrm{Cl}) \mathrm{X}_{2} \mathrm{CCX}_{2}\left(\mathrm{O}_{2}\right) \\
2(\mathrm{Cl}) \mathrm{X} 2 \mathrm{CCX} 2(\mathrm{O})+\mathrm{O} 2 \\
(\mathrm{Cl}) \mathrm{X}_{2} \mathrm{CCX}_{2}(\mathrm{O}) \rightarrow(\mathrm{Cl}) \mathrm{X}_{2} \mathrm{CCXO}+\mathrm{Cl}(\text { if one } \mathrm{X}=\mathrm{Cl}) \\
\text { or }(\mathrm{Cl}) \mathrm{X}_{2} \mathrm{CCX}_{2}(\mathrm{O}) \rightarrow \mathrm{CX}_{2} \mathrm{Cl}+\mathrm{COX}_{2}
\end{gathered}
$$

\begin{tabular}{|l|l|l|}
\hline Molecule & Electron $\left[\mathrm{cm}^{3} . \mathrm{s}^{-1}\right]$ & $\mathrm{Cl}\left[\mathrm{cm}^{3} . \mathrm{s}^{-1}\right]$ \\
\hline $\mathrm{CH}_{3} \mathrm{Cl}$ & $6.1 \times 10^{-11}, \quad \mathrm{Cl}^{-}+\mathrm{CH}_{3}$ & $4.78 \times 10^{-13}, \mathrm{CH}_{2} \mathrm{Cl}+\mathrm{HCl}$ \\
\hline $\mathrm{CH}_{2} \mathrm{Cl}_{2}$ & $1.6 \times 10^{-10}, \quad \mathrm{Cl}^{-}+\mathrm{CH}_{2} \mathrm{Cl}$ & $3.5 \times 10^{-13}, \quad \mathrm{CHCl}_{2}+\mathrm{HCl}$ \\
\hline $\mathrm{CHCl}_{3}$ & $4.9 \times 10^{-9}, \quad \mathrm{Cl}^{-}+\mathrm{CHCl}_{2}$ & $1.2 \times 10^{-13}, \quad \mathrm{CCl}_{3}+\mathrm{HCl}$ \\
\hline $\mathrm{CCl}_{4}$ & $1 \times 10^{-7}, \quad \mathrm{Cl}^{-}+\mathrm{CCl}_{3}$ & $1.4 \times 10^{-10}, \quad \mathrm{CCl}_{3}+\mathrm{Cl}_{2}$ \\
\hline $\mathrm{C}_{2} \mathrm{H}_{3} \mathrm{Cl}$ & $(1 \sim 8) \times 10^{-10}, \quad \mathrm{Cl}^{-}+\mathrm{C}_{2} \mathrm{H}_{3}$ & $1.27 \times 10^{-10}, \mathrm{CH}_{2} \mathrm{ClCHCl}$ \\
\hline $\mathrm{C}_{2} \mathrm{H}_{2} \mathrm{Cl}_{2}$ & $1 \times 10^{-9}, \quad \mathrm{Cl}^{-}+\mathrm{C}_{2} \mathrm{H}_{2} \mathrm{Cl}$ & $1.4 \times 10^{-10}, \quad \mathrm{CH}_{2} \mathrm{ClCCl}_{2}$ \\
\hline $\mathrm{C}_{2} \mathrm{HCl}_{3}$ & $(0.29 \sim 1) \times 10^{-8}, \mathrm{Cl}^{-}+\mathrm{C}_{2} \mathrm{HCl}_{2}$ & $9.3 \times 10^{-12}, \quad \mathrm{CCl}_{3} \mathrm{CHCl}$ \\
\hline $\mathrm{C}_{2} \mathrm{Cl}_{4}$ & $1 \times 10^{-7}, \quad \mathrm{Cl}^{-}+\mathrm{C}_{2} \mathrm{Cl}_{3}$ & $(4 \sim 6) \times 10^{-11}, \mathrm{C}_{2} \mathrm{Cl}_{5}$ \\
\hline $\mathrm{C}_{2} \mathrm{H}_{5} \mathrm{Cl}$ & $(2 \sim 7) \times 10^{-13}, \quad \mathrm{Cl}^{-}+\mathrm{C}_{2} \mathrm{H}_{5}$ & $6.8 \times 10^{-12}, \quad \mathrm{CH}_{3} \mathrm{CHCl}+\mathrm{HCl}$ \\
\hline
\end{tabular}

Table 3. Rate constants and products for the reactions of electron, $\mathrm{Cl}$ with chlorinated aliphatic compounds. 
The decomposition efficiency of Cl-HC mainly depends on the rate constants of secondary electron attachment, and $\mathrm{Cl}$ addition reaction followed by peroxyl radical reactions (Knox et al., 1966, 1969; Thúner et al., 1999). This decomposition pathway has been confirmed experimentally (Hirota et al., 2002).

$\mathrm{O}_{2}$ - cause $\mathrm{Cl}-\mathrm{HC}$ decomposition, $\mathrm{O}_{2}^{-}+\mathrm{M}=\mathrm{O}_{2}+\mathrm{M}^{-}(\mathrm{M}=\mathrm{Cl}-\mathrm{HC})$ (14)

$\mathrm{O}$ atom, $\mathrm{OH}$ radical , and other radical reactions with $\mathrm{Cl}-\mathrm{HC}$

Other decomposition pathways for chlorinated aliphatic hydrocarbons are: $\mathrm{O}$ atom decomposition pathway (Sanhueza et al., 1974a, 1974b; Teruel, et al., 2001), OH radical decomposition pathway (Atkinson, R., 1987b; Howard, et al., 1976; Liu et al., 1989; Chandra et al., 1999; Chang et al., 1977) and other species decomposition pathway, such as $\mathrm{O}_{3}$ and $\mathrm{NO}_{3}$. The rate constants of $\mathrm{O}$ and $\mathrm{OH}$ with $\mathrm{Cl}-\mathrm{HC}$, and the products of these reactions are listed in table 4, respectively (http://kinetics.nist.gov/kinetics/index.jsp). By-products of irradiation vary with reactants.

\begin{tabular}{|l|lll|}
\hline Molecule & $\mathrm{O}\left[\mathrm{cm}^{3} \cdot \mathrm{s}^{-1}\right]$ & $\mathrm{OH}\left[\mathrm{cm}^{3} . \mathrm{s}^{-1}\right]$ \\
\hline $\mathrm{CH}_{3} \mathrm{Cl}$ & $1.18 \times 10^{-16}, \quad \mathrm{OH}+\mathrm{CH}_{2} \mathrm{Cl}$ & $4.2 \times 10^{-14}, \quad \mathrm{CH}_{2} \mathrm{Cl}+\mathrm{H}_{2} \mathrm{O}$ \\
\hline $\mathrm{CH}_{2} \mathrm{Cl}_{2}$ & $6.48 \times 10^{-16}, \quad \mathrm{OH}+\mathrm{CHCl}_{2}$ & $1.4 \times 10^{-13}, \quad \mathrm{CHCl}_{2}+\mathrm{H}_{2} \mathrm{O}$ \\
\hline $\mathrm{CHCl}_{3}$ & $1.02 \times 10^{-15}, \quad \mathrm{OH}+\mathrm{CCl}_{3}$ & $1.0 \times 10^{-13}, \quad \mathrm{CCl}_{3}+\mathrm{H}_{2} \mathrm{O}$ \\
\hline $\mathrm{CCl}_{4}$ & $1.89 \times 10^{-16}, \quad \mathrm{ClO}+\mathrm{CCl}_{3}$ & $<4 \times 10^{-16}, \quad \mathrm{CCl}_{3}+\mathrm{HOCl}$ \\
\hline $\mathrm{C}_{2} \mathrm{H}_{3} \mathrm{Cl}$ & $5.96 \times 10^{-13}, \quad$ products & $8.06 \times 10^{-12}, \quad \mathrm{CHClCH}_{2} \mathrm{OH}$ \\
\hline $1,1-\mathrm{C}_{2} \mathrm{H}_{2} \mathrm{Cl}_{2}$ & $9.8 \times 10^{-13}, \quad$ products & $8.10 \times 10^{-12}, \quad \mathrm{CH}_{2} \mathrm{OHCCl}{ }_{2}$ \\
\hline $\mathrm{C}_{2} \mathrm{HCl}_{3}$ & $1.4 \times 10^{-13}, \quad$ products & $2.2 \times 10^{-12}, \quad$ products \\
\hline $\mathrm{C}_{2} \mathrm{Cl}_{4}$ & $1.9 \times 10^{-13}, \quad$ products & $1.7 \times 10^{-13}, \quad$ products \\
\hline $\mathrm{C}_{2} \mathrm{H}_{5} \mathrm{Cl}$ & $1.12 \times 10^{-15}, \mathrm{OH}+$ other products & $6.42 \times 10^{-13}, \mathrm{H}_{2} \mathrm{O}+$ other products \\
\hline
\end{tabular}

Table 4. Rate constants and products for the reactions of $\mathrm{O}, \mathrm{OH}$ with chlorinated aliphatic compounds

The mechanism of decomposition of chlorinated aliphatic hydrocarbons under EB irradiation could be described as follows: $\mathrm{Cl}^{-}$dissociative secondary electron attachment followed by peroxyl radicals reaction is a main path for $\mathrm{Cl}-\mathrm{HC}$ decomposition, positive and negative charge transfer reactions with $\mathrm{Cl}-\mathrm{HC}, \mathrm{O}$ atoms and other radicals reactions with $\mathrm{Cl}-$ $\mathrm{HC}$ cause $\mathrm{Cl}-\mathrm{HC}$ degradation too.

\subsubsection{General mechanism of chlorinated aromatic hydrocarbons ( $\mathrm{Cl}-\mathrm{AH})$ decomposition under EB-irradiation}

Similar to the mechanism of chlorinated alipathic hydrocarbons under EB-irradiation, the mechanism of chlorinated aromatic hydrocarbons go through secondary electron attachment and positive charge transfer reactions at the beginning stage of irradiation. At the late stage of irradiation, radical reactions play very important role for chlorinated aromatic hydrocarbon decomposition. Because rate constants of $\mathrm{Cl}$ radicals with chlorinated aromatic hydrocarbons (usually $1.0 \times 10^{-15} \sim 1.0 \times 10^{-16}$ ) (Shi \& Bernhard, 1997) are much smaller than those of $\mathrm{OH}$ radicals $\left(1.0 \times 10^{-12} \sim 1.0 \times 10^{-13}\right), \mathrm{Cl}$ radical addition reaction followed by peroxyl radical reaction pathway is not so important for chlorinated aromatic hydrocarbon decomposition in air mixture; on the contrary, $\mathrm{OH}$ radical reaction pathway is more important for chlorinated aromatic hydrocarbon decomposition in low or high humidity air mixture (Sun et al., 2007c). 
Some positive charge transfer reactions, such as $\mathrm{N}_{2}{ }^{+}$, cause benzene ring cleavage of chlorinated aromatic hydrocarbons. Aliphatic byproducts are formed. Hirota et al.(2000) and Han et al. (2003) observed some aliphatic organic compounds formed from chlorobenzene decomposition in air mixture under EB-irradiation.

The generalized chemical reactions could be written as follows:

$$
\begin{gathered}
\mathrm{Cl}-\mathrm{AH}+\mathrm{M}^{+}=\mathrm{M}+(\mathrm{Cl}-\mathrm{AH})^{+}\left(\mathrm{M}^{+}=\mathrm{N}_{2}{ }^{+}, \mathrm{O}_{2}{ }^{+}, \mathrm{N}^{+}, \mathrm{O}^{+}, \mathrm{NO}^{+}, \mathrm{H}_{3} \mathrm{O}^{+} \text {ect. }\right) \\
\left.(\mathrm{Cl}-\mathrm{AH})^{+}=\text {products (including ring cleavege reactions }\right) \\
(\mathrm{Cl}-\mathrm{AH})^{+}+(\text {radicals } / \text { neutral })=\text { products } \\
\mathrm{e}+(\mathrm{Cl}-\mathrm{AH})=\mathrm{Cl}^{-}+(\mathrm{AH}) \\
\mathrm{OH}+(\mathrm{Cl}-\mathrm{AH})=\text { products } \\
\mathrm{Cl}+(\mathrm{Cl}-\mathrm{AH})=\text { products } \\
(\mathrm{AH})+\left(\text { Radicals }, \text { neutral or } \mathrm{M}^{+}\right)=\text {products }
\end{gathered}
$$

\subsection{Nonchlorinated organic compounds}

For nonchlorinated aromatic organic compounds, VOCs decomposition mainly go through:

- Positive ions' charge transfer reactions:

$$
\mathrm{M}^{+}+\mathrm{RH}(\mathrm{RH}=\mathrm{VOC})=\mathrm{M}+\mathrm{RH}^{+}
$$

Because RH has lower ionisation energy (IE) ( for eg., $\mathrm{IE}_{\text {benzene }}=9.24 \mathrm{eV}$; $\mathrm{IE}_{\mathrm{PAHs}}<10 \mathrm{eV}$ ) than most primary positive ions (IE $>11 \mathrm{eV}$ ), such as $\mathrm{N}_{2}{ }^{+}, \mathrm{O}_{2}{ }^{+}$formed from radiolysis of base gas, part of VOC will be decomposed by rapid charge transfer reactions.

- $\quad$ Radical-neutral particles reactions

$\mathrm{OH}$ radicals play very important role for VOC decomposition, especially when water concentration is above $1 \%$. OH radicals react with VOC in two ways:

$\mathrm{OH}$ radicals addition to the aromatic ring or $\mathrm{H}$ atom abstraction (e.g. toluene)

$$
\begin{gathered}
\mathrm{OH}+\mathrm{C}_{6} \mathrm{H}_{5} \mathrm{CH}_{3}=\mathrm{R} 1 \text { (OH radical addition) } \\
\mathrm{C}_{6} \mathrm{H}_{5} \mathrm{CH}_{3}+\mathrm{OH}=\mathrm{R} 2+\mathrm{H}_{2} \mathrm{O} \text { (H atom abstraction) }
\end{gathered}
$$

Radicals (R1, R2) formed above go through very complex reactions: $\mathrm{O}_{2}$ addition, $\mathrm{O}$ atom release, aromatic- $\mathrm{CHO}$ (-dehydes), $-\mathrm{OH}$ compounds formed or ring cleavage products:

$$
\begin{gathered}
\mathrm{R}+\mathrm{O}_{2}=\mathrm{RO}_{2} \\
2 \mathrm{RO}_{2}=2 \mathrm{RO}+\mathrm{O}_{2} \\
\mathrm{RO}_{2}+\mathrm{NO}=\mathrm{RO}+\mathrm{NO}_{2} \\
\mathrm{RO}+\mathrm{O}_{2}=\mathrm{HO}_{2}+\text { products (aromatic }-\mathrm{CHO},-\mathrm{OH} \text { ) } \\
\mathrm{RO} \rightarrow \text { aliphatic products }
\end{gathered}
$$




\section{Conclusion}

Electron beam technology to treat organic compounds has been studied for many years. Based on experiments of lab scale in batch system and flow system and experiments of pilot scale, it was shown that aliphatic organic compounds $(\mathrm{C} \leq 4)$ are easily to be decomposed by electron beam technology, the enegy necessary to decompose aliphatic hydrocarbons in the order of lower to higher: chlorinated unsaturated hydrocarbons, chlorinated saturated hydrocarbons, hydrocarbons. For aromatic hydrocarbons decomposition in gas phase, energy is much higher than that used to decompose aliphatic hydrocarbons. About $70 \%$ aromatic VOCs are decomposed at $20 \mathrm{kGy}$ absorbed dose for most single ring aromatic hydrocabons.

Organic compounds in gas mixture can be decomposed by EB-irradiation, and the decomposition efficiency of organic pollutants increases with the absorbed dose. For chlorinated aliphatic hydrocarbons, the decomposition efficiency of unsaturated (with double $\mathrm{C}=\mathrm{C}$ bond) hydrocarbons is higher than that of saturated hydrocarbons, and the decomposition efficiency of chlorinated compounds with higher numbers of chlorine groups is higher than observed for the compounds with lower number of chlorine groups. Decomposition efficiency of chlorinated aromatic hydrocarbons is lower than chlorinated unsaturated (with double $\mathrm{C}=\mathrm{C}$ bonds) aliphatic hydrocarbons.

Different matrix gas and some additives influence the organic pollutants decomposition. For chlorinated aliphatic hydrocarbons, the decomposition efficiency of $\mathrm{Cl}-\mathrm{HC}$ in oxygen or air is higher thanthat observed in nitrogen; and for chlorinated aromatic hydrocarbons (such as 1,4-DCB) the decomposition efficiency of $\mathrm{Cl}-\mathrm{HC}$ in nitrogen is higher than that in air. The reason for this can be explained by their different decomposition mechanisms. Water vapor injection and $\mathrm{NH}_{3}$ addition increase decomposition efficiency of organic pollutants.

Removal efficiency of organic pollutants in hybrid system (EB + catalyst) is higher than that in EB or catalyst system only.

Mechanism of organic pollutants decomposition is composed of following steps. At the early stage of EB irradiation, secondary electrons interact with the base gas mixture components and positive and negative charge transfer reactions play important roles for organic pollutants decomposition. At the latter stage of EB-irradiation, radical reactions play important roles for organic pollutants decomposition.

\section{Acknowledgment}

This contribution is financed by "PlasTEP: Dissemination and fostering of plasma based technological innovation for environment protection in BSR" (Project No \#033 of the Baltic Sea Region Program 2007-2013)", and this financial support is greatly acknowledged.

\section{References}

Atkinson, R.(1987a). Kinetics of the Gas-Phase Reactions of Cl Atoms with Chloroethenes at 298.72K and Atmosphere Pressure. International Journal of Chemical Kinetics, Vol.19, No.12, pp.1097-1105, ISSN 0538-8066

Atkinson, R. (1987b). A Structure-Activity Relationship for the Estimation of Rate Constants for the Gas-Phase Reactions of $\mathrm{OH}$ Radicals with Organic Compounds. International Journal of Chemical Kinetics, Vol.19, No.9, pp.799-828, ISSN 0538-8066 
Bryukov, M.G.; Slagle, I.R.\& Knyazev, V.D.(2002). Kinetics of Reactions of Cl Atoms with Methane and Chlorinated Methanes. The journal of physical chemistry A, Vol. 106, No.44, pp.10532 -10542, ISSN 1089-5639

Callén, M.S.; de la Cruz, M.T.; Marinov, S.; Stefanova, M.; Murillo, R. \& Mastral, A.M. (2007). Flue Gas Cleaning in Power Stations by Using Electron Beam Technology. Influence on PAH Emissions. Fuel Processing Technology, Vol. 88, No.3, pp. 251-258, ISSN 0378-3820

Chandra, A.K. \& Uchimaru, T.(1999). An Ab Initio Investigation of the Reactions of 1,1- and 1,2- Dichloroethane with Hydroxyl Radical. The journal of physical chemistry A, Vol.103, No.50, pp. 10847-10883, ISSN 1089-5639.

Chang, J.S. \& Kaufman, F.(1977). Kinetics of the Reactions of Hydroxyl Radicals with Some Halocarbons: $\mathrm{CHFCl}_{2}, \mathrm{CHF}_{2} \mathrm{Cl}, \mathrm{CH}_{3} \mathrm{CCl}_{3}, \mathrm{C}_{2} \mathrm{HCl}_{3}$, and $\mathrm{C}_{2} \mathrm{Cl}_{4}$. Journal of Chemical Physics, Vol.66, No.11, pp.4989-4994, ISSN 0021-9606

Chmielewski, A.G.; Ostapczuk, A.; Zimek, Z.; Licki, J. \& Kubica, K. (2002). Reduction of VOCs in Flue Gas from Coal Combustion by Electron Beam Treatment. Radiation Physics and Chemistry, Vol. 63, No.3-6, pp. 653-655, ISSN 0969-806X

Chmielewski, A.G.; Sun, Y.; Licki, J.; Bulka, S.; Kubica, K. \& Zimek, Z. (2003). NOx and PAHs Removal from Industrial Flue Gas by using Electron Beam Technology with Alcohol Addition, Radiation Physics and Chemistry, Vol. 67,No.3-4, pp. 555-560, ISSN 0969-806X

Chmielewski, A.G.; Licki, J.; Pawelec, A.; Tymiński, B. \& Zimek, Z. (2004a). Operational Experience of the Industrial Plant for Electron Beam Flue Gas Treatment. Radiation Physics and Chemistry, Vol.71, No.1-2, pp.439-442, ISSN 0969-806X.

Chmielewski, A.G.; Sun, Y.-X.; Bulka, S. \& Zimek, Z. (2004b). Chlorinated Aliphatic and Aromatic VOC Decomposition in Air Mixture by Using Electron Beam Irradiation. Radiation Physics and Chemistry, Vol. 71,No.1-2, pp. 435-438, ISSN 0969-806X

Hakoda, T.; Hirota, K. \& Hashimoto, S. (1998a). Decomposition of Tetrachloroethylene by Ionizing Radiation (IAEA-SM-350/4). Radiation Technology for Conservation of the Environment, Proceeding of a symposium held in Zakopane, Poland, 8-12 September 1997, IAEA-TECDOC-1023, pp. 55-66, ISSN 1011-4289

Hakoda, T.; Yang, M.; Hirota, K. \& Hashimoto, S. (1998b). Decomposition of Volatile Organic Compounds in Air by Electron Beam and Gamma Ray Irradiation. Journal of Advanced Oxidation Technologies, Vol. 3, pp.79-86, ISSN 1203-8407

Hakoda, T.; Zhang, G. \& Hashimoto, S. (1999). Decomposition of Chloroethenes in Electron Beam Irradiation. Radiation Physics and Chemistry, Vol. 55, No.5-6, pp. 541-546, ISSN 0969-806X

Hakoda, T.; Hashimoto, S.; Fujiyama, Y. \& Mizuno, A. (2000). Decomposition Mechanism for Electron Beam Irradiation of Vaporized Trichloroethylene-Air Mixtures. The journal of physical chemistry. A, Vol. 104, No.1, pp.59-66, ISSN 1089-5639

Hakoda, T.; Zhang, G. \& Hashimoto, S. (2001). Chain Oxidation Initiated by $\mathrm{OH}, \mathrm{O}\left({ }^{3 \mathrm{P}}\right)$ Radicals, Thermal Electrons, and $\mathrm{O}_{3}$ in Electron Beam Irradiation of 1,2Dichloroethylenes and Air Mixtures. Radiation Physics and Chemistry, Vol. 62, No.23, pp.243-252, ISSN 0969-806X

Hakoda, T.; Matsumoto, K.; Mizuno, A.; Kojima, T. \& Hirota, K. (2008a). Catalytic Oxidation of Xylene in Air using $\mathrm{TiO}_{2}$ under Electron Beam Irradiation. Radiation Physics and Chemistry, Vol. 28, No.1, pp. 25-37, ISSN 0969-806X 
Hakoda, T.; Shimada, A. \& Hirota, K. (2008b). Development of Removal Technology for Volatile Organic Compounds (VOCs) using Electron Beams, International Conference on Recent Developments and Applications of Nuclear Technologies, pp. 200, ISBN 978-83909690-8-4, Białowieża, Poland, September 15-17, 2008.

Han, D.H.; Stuchinskaya, T.; Won, Y.S.; Park, W.S. \& Lim, J.K. (2003). Oxidative Decomposition of Aromatic Hydrocarbons by Electron Beam Irradiation. Radiation Physics and Chemistry, Vol. 67,No.1, pp. 51-60, ISSN 0969-806X

Hashimoto, S.; Hakoda, T.; Hitora, K. \& Arai, H. (2000). Low Energy Electron Beam Treatment of VOCs. Radiation Physics and Chemistry, Vol. 57, No.3-6, pp. 485-488, ISSN 0969-806X

Hirota, K.; Hakoda, T.; Arai, H.\& Hashimoto, S.(2000). Dechlorination of Chlorobenzene in Air with Electron Beam. Radiation Physics and Chemistry, Vol. 57, No.1, pp. 63-73, ISSN 0969-806X

Hirota, K.; Hakoda, T.; Arai, H.\& Hashimoto, S.(2002). Electron-Beam Decomposition of Vaporized VOCs in Air. Radiation Physics and Chemistry, Vol. 65, No. 4-5, pp. 415427, ISSN 0969-806X

Hirota, K.; Hakoda, T.; Taguchi, M.; Takigami, M.; Kim, H. \& Kojima, T. (2003). Application of Electron Beam for the Reduction of PCDD/F Emission from Municipal Solid Waste Incinerators. Environmental Science \& Technology, Vol.37, No.14, pp. 31643170, ISSN 0013-936X

Hirota, H.; Sakai, H.; Washio, M. \& Takuji, K. (2004). Application of Electron Beams for the Treatment of VOC Streams. Industrial \& Engineering Chemistry Research, Vol.43, No.5, pp. 1185-1191, ISSN 0888-5885

Howard, C.J. (1976). Rate Constants for the Gas-Phase Reactions of OH Radicals with Ethylene and Halogenated Ethylene Compounds. Journal of Chemical Physics, Vol.65, No.11, pp. 4771-4777, ISSN 0021-9606

Ighigeanu, D.; Calinescu , I.; Martin, D. \& Matei, C. (2008). A New Hybrid Technique for the Volatile Organic Compounds Removal by Combined Use of Electron Beams, Microwaves and Catalysts. Nuclear Instruments and Methods in Physics Research B, Vol. 266, No.10, pp. 2524-2528, ISSN 0168-583X

Jeon, E.C.; Kim, K.J.; Kim, J.C.; Kim, K.H.; Chung, S.G.; Sunwoo, Y. \& Park, Y.K. (2008). Novel Hybrid Technology for VOC Control using an Electron Beam and Catalyst. Research on Chemical Intermediates, Vol.34, No.8-9, pp. 863-870, ISSN 0922-6168

Kim, J.C. (2002). Factors Affecting Aromatic VOC Removal by Electron Beam Treatment. Radiation Physics and Chemistry, Vol. 65, No. 4-5 , pp. 429-435, ISSN 0969-806X

Kim, J.; Han, B.; Kim, Y.; Lee, J.H.; Park, C.R.; Kim, J.C. \& Kim, K.J. (2004). Removal of VOCs by Hybrid Electron Beam Reactor with Catalyst Bed. Radiation Physics and Chemistry, Vol. 71, No.1-2 , pp. 427-430, ISSN 0969-806X

Kim, K.J.; Kim, J.C.; Kim, J. \& Sunwoo, Y. (2005). Development of Hybrid Technology using E-Beam and Catalyst for Aromatic VOCs Control. Radiation Physics and Chemistry, Vol. 73, No.2, pp. 85-90, ISSN 0969-806X

Knox, J. H. \& Riddick, J. (1966). Activated Chloroethyl Radicals in the Chlorination of 1,2Dichloroethylenes. Transactions of the Faraday Society, Vol. 62, pp. 1190-1205, ISSN 0956-5000

Knox, J. \& Waugh, K.C. (1969). Activated Chloroalkyl Radicals in the Chlorination of Trichloroethylene and Other Olefins. Transactions of the Faraday Society ,Vol.65, pp.1585-1594, ISSN 0956-5000 
Liu, A.; Mulac, W.A. \& Jonah, C. D. (1989). Pulse Radiolysis Study of the Gas-Phase Reaction of $\mathrm{OH}$ Radicals with Vinyl Chloride at $1 \mathrm{~atm}$ and Over the Temperature Range 3131173 K. The Journal of Physical Chemistry, Vol.93, No.10, pp. 4092-4094, ISSN 10895639

Machi, S. (1983). Radiation Technology for Environmental Conservation. Radiation Physics and Chemistry, Vol. 22, No. 1-2, pp. 91-97, ISSN 0969-806X

Mätzing, H. (1989). Chemical Kinetics of Flue Gas Cleaning by Irradiation with Electrons. In: Advances in Chemical Physics Volume LXXX , I. Prigogine, \& S.A.Rice, (Ed.), 315-402, John Wiley \& Sons. Inc., ISBN 0-471-53281-9

Nichipor, H.; Dashouk, E.; Chmielewski, A.G.; Zimek, Z. \& Bułka, S. (2000). A Theoretical Study on Decomposition of Carbon Tetrachloride, Trichloroethylene and Ethyl Chloride in Dry Air under the Influence of an Electron Beam. Radiation Physics and Chemistry, Vol. 57, No.3-6, pp. 519-525, ISSN 0969-806X

Nichipor, H.; Dashouk, E.; Yacko, S.; Chmielewski, A.G.; Zimek, Z. \& Sun, Y. (2002). Chlorinated Hydrocarbons and PAHs Decomposition in Dry and Humid Air by Electron Beam Irradiation. Radiation Physics and Chemistry, Vol. 65, No.4-5, pp. 423427, ISSN 0969-806X

Nichipor,H.; Dashouk, E.; Yacko, S.; Chmielewski, A.G.; Zimek, Z.; Sun, Y. \& Vitale, S.A. (2003). The Kinetics of 1,1-Dichloroethene $\left(\mathrm{CCl}_{2}=\mathrm{CH}_{2}\right)$ and Trichloroethene $\left(\mathrm{HClC}=\mathrm{CCl}_{2}\right)$ Decomposition in Dry and Humid Air under the Influence of Electron Beam. Nukleonik, Vol. 48, No.1, pp.45-50, ISSN 0029-5922

Nichipor, H.; Yacko,S.; Sun, Y.; Chmielewski, A.G. \& Zimek, Z.(2008). Theoretical Study of Dose and Dose Rate Effect on Trichloroethylene $\left(\mathrm{HClC}=\mathrm{CCl}_{2}\right)$ Decomposition in Dry and Humid Air under Electron Beam Irradiation. Nukleonik, Vol. 53, No.1, pp.11-16, ISSN 0029-5922

Ostapczuk, A.; Chmielewski, A.G.; Honkonen, V.; Ruuskanen,J.; Tarhanen, J. \& Svarfvar, B.(1999). Preliminary Test in Decomposition of Styrene by Electron Beam Treatment. Radiation Physics and Chemistry, vol 56, No.4, pp. 369-371, ISSN 0969$806 \mathrm{X}$

Ostapczuk, A.; Licki, J. \& Chmielewski, A. (2008a). Polycyclic Aromatic Hydrocarbons in Coal Combustion Flue Gas under Electron Beam Irradiation. Radiation Physics and Chemistry, vol 77, No.4, pp. 490-496, ISSN 0969-806X

Ostapczuk, A.; Hakoda, T.; Shimada, A. \& Kojima, T. (2008b). Naphthalene and Acenaphthene Decomposition by Electron Beam Generated Plasma Application. Plasma Chemistry and Plasma Processing, Vol. 28, No. 4, pp. 483-494, ISSN 0272-4324

Paur, H.-R. (1998). Decomposition of Volatile Organic Compounds and Polycyclic Aromatic hydrocarbons in industrial off gas by electron beam - a review (IAEA-SM-350/52). Radiation Technology for Conservation of the Environment, Proceeding of a symposium held in Zakopane, Poland, 8-12 September 1997, IAEA-TECDOC-1023, pp. 67-85, ISSN 1011-4289

Prager, L.; Langguth, H.; Rummel, S. \& Mehnert, R. (1995). Electron Beam Degradation of Chlorinated Hydrocarbons in Air. Radiation Physics and Chemistry, vol 46, No.4-6, pp. 1137-1142, ISSN 0969-806X

Sanhueza, E. \& Heickien, J. (1974a). The Reaction of $\mathrm{O}\left({ }^{3} \mathrm{P}\right)$ with $\mathrm{C}_{2} \mathrm{Cl}_{4}$. Canadian Journal of Chemistry, Vol.52, No.23, pp.3870-3878, ISSN 0008-4042

Sanhueza, E. \& Heickien, J. (1974b). The Reaction of $\mathrm{O}\left({ }^{3} \mathrm{P}\right)$ with $\mathrm{C}_{2} \mathrm{HCl}_{3}$. International Journal of Chemical Kinetics, Vol.6, No.4, pp.553-565, ISSN (printed) 0538-8066, ISSN (electronic) 1097-4601 
Shi, J. \& Bernhard, M.J. (1997). Kinetic Studies of Cl-atom Reactions with Selected Aromatic Compounds using the Photochemical Reactor-FTIR Spectroscopy Technique. International Journal of Chemical Kinetics, Vol. 29, No.5, pp. 349-358, ISSN 0538-8066

Slater, R.C. \& Douglas-Hamilton, D.H. (1981). Electron-Beam-Initiated Destruction of Low Concentrations of Vinyl Chloride in Carrier Gases. Journal of Applied Physics, Vol. 52, No.9, pp. 5820-5828. ISSN 0021-8979

Son, Y.S.; Kim, J.; Kim, K. \& Son, Y.S. (2008). VOC Removal Characteristics for E-BeamCatalyst Coupling with Respect to Catalysts and Humidity, Recent developments and Applications of Nuclear Technologies, pp.201-201, ISBN 978-83-909690-8-4, Białowieża, Poland, Sept 15-17, 2008.

Son, Y.S.; Park, K.N. \& Kim, J.C. (2010a). Control Factors and By-Products During Decomposition of Butane in Electron Beam Irradiation. Radiation Physics and Chemistry, Vol.79, No.12, pp. 1255-1258, ISSN 0969-806X

Son, Y.S.; Kim, K.J.; Kim, J.Y. \& Kim, J.C. (2010b). Comparison of the Decomposition Characteristics of Aromatic VOCs Using an Electron Beam Hybrid System. Radiation Physics and Chemistry, Vol.79, No.12, pp. 1270-1274, ISSN 0969-806X

Spanel, P. \& Smith, D. (1999a). Seleted Ion Flow Tube Studies of the Reactions of $\mathrm{H}_{3} \mathrm{O}^{+}, \mathrm{NO}^{+}$, and $\mathrm{O}_{2}{ }^{+}$with Some Chloroalkanes and Chloroalkenes. International Journal of Mass Spectrometry. Vol. 184, No. 2-3, pp.175-181, ISSN 1387-3806

Spanel, P. \& Smith, D. (1999b). Seleted Ion Flow Tube Studies of the Reactions of $\mathrm{H}_{3} \mathrm{O}^{+}, \mathrm{NO}^{+}$, and $\mathrm{O}_{2}{ }^{+}$with Several Aromatic and Aliphatic Monosubstituted Halocarbons. International Journal of Mass Spectrometry. Vol.189, No. 2-3, pp. 213-223, ISSN 1387-3806

Srivastava, R.K.; Jozewicz, W. \& Singer, C.(2001). $\mathrm{SO}_{2}$ Scrubbing Technologies: a Review. Environmental Progress, Vol. 20, No.4, pp. 219-228, ISSN 0278-4491

Sun, Y.; Hakoda, T.; Chmielewski, A.G.; Hashimoto, S.; Zimek, Z.; Bułka, S.; Ostapczuk, A. \& Nichipor, H. ( 2001). Mechanism of Decomposition of 1,1-Dichloroethylene in Humid Air under Electron beam Irradiation. Radiation Physics and Chemistry, Vol. 62, No.4, pp. 353-360, ISSN 0969-806X

Sun, Y.; Hakoda, T.; Chmielewski, A.G. \& Hashimoto, S. (2003). Trans-1,2- Dichloroethylene Decomposition in Low-Humidity Air under Electron Beam Irradiation. Radiation Physics and Chemistry, Vol. 68, No.5, pp. 843-850, ISSN 0969-806X

Sun, Y. \& Chmielewski, A.G. (2004). 1,2-Dichlroethylene Decomposition in Air Mixture Using Ionization Technology. Radiation Physics and Chemistry, Vol. 71, No.1-2, pp. 433-436, ISSN 0969-806X

Sun, Y.; Chmielewski,A.G.; Bułka, S.\& Zimek, Z.(2006). Influence of Base Gas Mixture on Decomposition of 1,4-Dichlorobenzene in an Electron Beam Generated Plasma Reactor. Plasma Chemistry and Plasma Processing, Vol. 26, No.4, pp. 347 - 359, ISSN: 0272-4324.

Sun, Y.; Chmielewski, A.G.; Bułka, S. \& Zimek, Z.(2007a). 1-Chloronaphthalene Decomposition in Different Gas Mixtures under Electron Beam Irradiation. Radiation Physics and Chemistry, Vol. 76, No.11-12, pp. 1802-1805, ISSN 0969-806X

Sun, Y.; Chmielewski, A.G.; Bułka, S.; Zimek, Z. \& Nichipor,H. (2007b). Simulation of Decomposition of Dichloroethylenes (trans-DCE, cis-DCE, 1,1-DCE)/Air under Electron Beam Irradiation. Nukleonik, Vol. 52, No.2, pp.59-67, ISSN 0029-5922

Sun, Y.; Chmielewski, A.G.; Bułka, S.; Zimek, Z. \& Nichipor,H. (2007c). Mechanism of Decomposition of 1,4-Dichlorobenzene/Air in an Electron Beam Generated Plasma Reactor. Radiation Physics and Chemistry, Vol. 76, No.7, pp. 1132-1139, ISSN 0969806X 
Sun, Y.; Chmielewski, A.G.; Bułka, S.\& Zimek, Z.(2008). Organic Pollutants Treatment in Gas Phase by Using Electron Beam Generated Non-Thermal Plasma Reactor. Chemické Listy 102, s1524-s1528, ISSN 1803-2389

Sun, Y.; Chmielewski, A.G.; Bułka, S.\& Zimek, Z. (2009a). Decomposition of Toluene in Air Mixtures Under Electron Beam Irradiation. Nukleonika, Vol. 54, No.2, pp.65-70, ISSN 0029-5922

Sun, Y.; Chmielewski, A.G.; Bułka, S.; Zimek, Z. \& Nichipor,H.(2009b). Simulation Calculations of Tetrachloroethylene Decomposition in Air Mixtures Under Electron Beam Irradiation. Radiation Physics and Chemistry, Vol. 78, No.7-8, pp. 715-719, ISSN 0969-806X

Szamrej, I.; Tchórzewska, W.; Kość, H. \& Foryś, M. (1996). Thermal Electron Attachment Processes in Halomethanes - Part I. $\mathrm{CH}_{2} \mathrm{Cl}_{2}, \mathrm{CHFCl}_{2}$ and $\mathrm{CF}_{2} \mathrm{Cl}_{2}$. Radiation Physics and Chemistry, Vol. 47, No.2, pp. 269-273, ISSN 0969-806X

Teruel, M.A.; Taccone, R.A. \& Lane, S.I. (2001). Gas-Phase Reactivity Study of O( $\left.{ }^{3} \mathrm{P}\right)$ atoms with Trans- $\mathrm{CHCl}=\mathrm{CHCl}$ and $\mathrm{CHCl}=\mathrm{CCl}_{2}$ at $298 \mathrm{~K}$ : Comparison to Reactions with Some Other Substituted Ethenes. International Journal of Chemical Kinetics, Vol. 33, No.7, pp. 415-421, ISSN 0538-8066

Thüner, L.P.; Barnes, I.; Becker, K.H.; Wallington, T.J.; Chrisensen, L.K.; Orlando, J.J. \& Ramacher, B. (1999). Atmospheric Chemistry of Tetrachloroethylene $\left(\mathrm{Cl}_{2} \mathrm{C}=\mathrm{CCl}_{2}\right)$ : Products of Chlorine Atom Initiated Oxidation. The journal of physical chemistry. A, Vol. 103, No.43, pp. 8657-8663, ISSN 1089-5639

Vitale, S.A.; Hadidi, K.; Cohn, D.R.; Falkos, P. \& Bromberg, L. (1996). Electron Beam Generated Plasma Decompositio of 1,1,1-Trichloroethane. Plasma Chemistry and Plasma Processing, Vol.16, No.4, pp. 651-668, ISSN 0272-4324

Vitale, S.A.; Hadidi, K.; Cohn, D.R. \& Bromberg, L. (1997a). Decomposition of Ethyl Chloride and Vinyl Chloride in an Electron Beam Generated Plasma Reactor. Radiation Physics and Chemistry, Vol. 49, No.4 , pp. 421-428, ISSN 0969-806X

Vitale, S.A.; Hadidi, K.; Cohn, D.R. \&, Bromberg, L. (1997b). Evaluation of the Reaction Rate Constants for Chlorinated Ethylene and Ethane Decomposition in AttachmentDominated Atmospheric Pressure Dry Air Plasmas. Physics Letter A, Vol. 232, No.6, pp. 447-455, ISSN 0375-9601

Vitale, S.A.; Hadidi, K.; Cohn, D.R. \& Bromberg, L. (1997c). Decomposition of 1,1Dichloroethane and 1,1-Dichloroethene in an Electron Beam Generated Plasma Reactor. Journal of Applied Physics, Vol.81, No.1, pp. 2863-2868, ISSN 0021-8979

Vitale, S.A.; Hadidi, K.; Cohn, D.R. \& Falkos, P. (1997d). The Effect of a Carbon-Carbon Double Bond on Electron Beam-Generated Plasma Decomposition of Trichloroethylene and 1,1,1-Trichloroethane. Plasma Chemistry and Plasma Processing, Vol.17, No.1, pp. 59-78, ISSN 0272-4324

Willis C. \& Boyd.A.W.(1976). Excitation in the Radiation Chemistry of Inorganic Gases. International Journal for Radiation Physics and Chemistry, Vol. 8, No.1-2, pp. 71-112, ISSN 0020-7055

Won, Y.-S.; Han, D.-H.; Stuchinskaya, T.; Park, W.-S. \& Lee, H.-S. (2002). Electron Beam Treatment of Chloroethylenes/Air Mixture in a Flow Reactor. Radiation Physics and Chemistry, Vol. 63, No.2, pp. 165-175, ISSN 0969-806X

Zimek, Z. (1995). High Power Electron Accelerators for Flue Gas Treatment. Radiation Physics and Chemistry, Vol. 45, No.6, pp. 1013-1015, ISSN 0969-806X

Zimek, Z. (2005). High Power Accelerators and Processing Systems for Environmental Application. Radiaiton Treatment of Gaseous and Liquid Effluents for Contaminant Removal, IAEA-TECDOC-1473, pp. 125-137, ISBN 92-0-110405-7, ISSN 1011-4289 


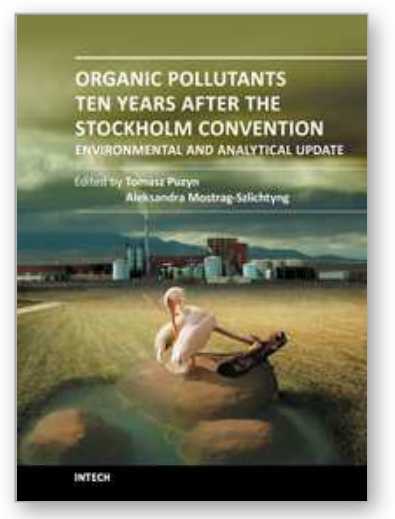

\section{Organic Pollutants Ten Years After the Stockholm Convention - Environmental and Analytical Update}

Edited by Dr. Tomasz Puzyn

ISBN 978-953-307-917-2

Hard cover, 472 pages

Publisher InTech

Published online 24, February, 2012

Published in print edition February, 2012

Ten years after coming into force of the Stockholm Convention on Persistent Organic Pollutants (POPs), a wide range of organic chemicals (industrial formulations, plant protection products, pharmaceuticals and personal care products, etc.) still poses the highest priority environmental hazard. The broadening of knowledge of organic pollutants (OPs) environmental fate and effects, as well as the decontamination techniques, is accompanied by an increase in significance of certain pollution sources (e.g. sewage sludge and dredged sediments application, textile industry), associated with a potential generation of new dangers for humans and natural ecosystems. The present book addresses these aspects, especially in the light of Organic Pollutants risk assessment as well as the practical application of novel analytical methods and techniques for removing OPs from the environment. Providing analytical and environmental update, this contribution can be particularly valuable for engineers and environmental scientists.

\section{How to reference}

In order to correctly reference this scholarly work, feel free to copy and paste the following:

Yongxia Sun and A. G. Chmielewski (2012). Organic Pollutants Treatment from Air Using Electron Beam Generated Nonthermal Plasma - Overview, Organic Pollutants Ten Years After the Stockholm Convention Environmental and Analytical Update, Dr. Tomasz Puzyn (Ed.), ISBN: 978-953-307-917-2, InTech, Available from: http://www.intechopen.com/books/organic-pollutants-ten-years-after-the-stockholm-conventionenvironmental-and-analytical-update/organic-pollutants-treatment-from-air-using-electron-beam-generatednonthermal-plasma-overview

\section{INTECH}

open science | open minds

\author{
InTech Europe \\ University Campus STeP Ri \\ Slavka Krautzeka 83/A \\ 51000 Rijeka, Croatia \\ Phone: +385 (51) 770447 \\ Fax: +385 (51) 686166 \\ www.intechopen.com
}

\author{
InTech China \\ Unit 405, Office Block, Hotel Equatorial Shanghai \\ No.65, Yan An Road (West), Shanghai, 200040, China \\ 中国上海市延安西路65号上海国际贵都大饭店办公楼405单元 \\ Phone: $+86-21-62489820$ \\ Fax: $+86-21-62489821$
}


(C) 2012 The Author(s). Licensee IntechOpen. This is an open access article distributed under the terms of the Creative Commons Attribution 3.0 License, which permits unrestricted use, distribution, and reproduction in any medium, provided the original work is properly cited. 